\title{
огляди
}

UDC 546.221.1

\section{HYDROGEN SULFIDE: METABOLISM, BIOLOGICAL AND MEDICAL ROLE}

\author{
N. V. ZAICHKO, A. V. MELNIK, M. M. YOLTUKHIVSKYY, \\ A. S. OLHOVSKIY, I. V. PALAMARCHUK
}

Pirogov Vinnytsya National Memorial Medical University, Ukraine

e-mail: nzaichko@mail.ru

Hydrogen sulfide $\left(\mathrm{H}_{2} \mathrm{~S}\right)$ is a signaling molecule that is actively synthesized in the tissues and is involved in the regulation of vascular tone, neuromodulation, cytoprotection, inflammation and apoptosis. In recent years, new data on animal and human $\mathrm{H}_{2} \mathrm{~S}$ metabolism and function under the effect of various endogenous and exogenous factors, including drugs were collected. This review is provided to introduce generalized information about the main and alternative $\mathrm{H}_{2} \mathrm{~S}$ metabolism and regulation, peculiarities of transport, signaling, biological role and participation in pathogenesis. Submitted data describe $\mathrm{H}_{2} \mathrm{~S}$ content and activity of $\mathrm{H}_{2} \mathrm{~S}$-synthesizing enzymes in different organs, $\mathrm{H}_{2} \mathrm{~S}$ effect on blood coagulation and platelet aggregation based on our research results. The working classification of $\mathrm{H}_{2} \mathrm{~S}$ metabolism modulators, which are used in biology and medicine, is proposed: 1) agents that increase $\mathrm{H}_{2} \mathrm{~S}$ content in tissues (inorganic and organic $\mathrm{H}_{2} \mathrm{~S}$ donors; $\mathrm{H}_{2} \mathrm{~S}$-synthesizing enzymes substrates and their derivatives, $\mathrm{H}_{2} \mathrm{~S}$-releasing drugs; agents that contain $\mathrm{H}_{2} \mathrm{~S}$-synthesizing enzymes cofactors and activators, agents that inhibit $\mathrm{H}_{2} \mathrm{~S}$ utilization); 2) agents that reduce $\mathrm{H}_{2} \mathrm{~S}$ content in tissues (specific and nonspecific inhibitors of $\mathrm{H}_{2} \mathrm{~S}$-synthesizing enzymes), 3) agents with uncertain impact on $\mathrm{H}_{2} \mathrm{~S}$ metabolism (some medicines). It was demonstrated that vitamin-microelement and microelement complexes with $\mathrm{H}_{2} \mathrm{~S}$-synthesizing enzymes cofactors and activators represent a promising approach for $\mathrm{H}_{2} \mathrm{~S}$ content correction in tissues.

Key words: hydrogen sulfide, $\mathrm{H}_{2} \mathrm{~S}$-signaling, enzymes, regulation, $\mathrm{H}_{2} \mathrm{~S}$ metabolism modulators, vitamin and microelement complexes.

$\mathrm{H}$ ydrogen sulfide $\left(\mathrm{H}_{2} \mathrm{~S}\right)$ is well-known as a toxic gas with obnoxious odour, which is mainly formed in the process of putrefaction of animal and plant proteins. Its role in living organisms was considered for a long time only from the viewpoint of exotoxicant and endotoxicant, meaning the inhibitor of cytochrome $c$ oxidase, monoamine oxidase, neurotoxin, and lung irritant. The interest to $\mathrm{H}_{2} \mathrm{~S}$ significantly increased from the beginning of the 90 's of the $20^{\text {th }}$ century because of determination of its connection with regulation of animal and human physiological functions. The results of studies of Kazuho Abe та Hideo Kimura (1996) have triggered more deep research of $\mathrm{H}_{2} \mathrm{~S}$ biological role. The studies described peculiarities of this metabolite production in rats' brain and identified its first molecular target: N-methyl-D-aspartate receptors (NMDA-receptors) [1].
$\mathrm{H}_{2} \mathrm{~S}$ is up to date a significant member of gasotransmitter family, including nitrogen monoxide (NO) and carbon monoxide (CO), and is involved in vascular tone regulation, neuromodulation, cytoprotection, inflammation, apoptosis and other processes [2-7]. Despite of the great number of foreign articles describing the role of $\mathrm{H}_{2} \mathrm{~S}$ in biology and medicine, the Ukrainian works on this issue are scarce. New information has been accumulated recently on metabolism and $\mathrm{H}_{2} \mathrm{~S}$ functions in organisms under the effect of different endogenous and exogenous factors, including medicines, which we tried to generalize in this review.

$\mathrm{H}_{2} \mathrm{~S}$ physicochemical properties and membrane transport. $\mathrm{H}_{2} \mathrm{~S}$ is a short-living molecule with half-life of a few minutes [2]. In aqueous solutions 20-30\% of $\mathrm{H}_{2} \mathrm{~S}$ exist in a non-dissociated form at $\mathrm{pH}$ 7.4 and $70-80 \%$ in a form of hydrosulfide anion $\left(\mathrm{H}_{2} \mathrm{~S}\right.$ 
$\leftrightarrow \mathrm{H}^{+}+\mathrm{HS} ; \mathrm{p} K_{\mathrm{a}} 6.89$ ), partially transforming into sulfide anion $\left(\mathrm{S}^{2-}\right)[3,8]$. $\mathrm{H}_{2} \mathrm{~S}$ possesses a high lipophility and is solved in lipid membranes two times easier (partition coefficient $-2.0 \pm 0.6$ ), than in water [8]. $\mathrm{H}_{2} \mathrm{~S}$ is characterized by high permeability coefficient of lipid membrane $\left(\mathrm{P}_{\mathrm{m}}=3 \mathrm{~cm} \cdot \mathrm{s}^{-1}\right)$ and easily diffuses throughout cell membranes [8]. In conditions of organism at $\mathrm{pH} 7.4$, the transmembrane diffusion of $\mathrm{H}_{2} \mathrm{~S}$ proceeds slower $\left(\mathrm{P}_{\mathrm{m} 7.4}=0.85 \mathrm{~cm} \cdot \mathrm{s}^{-1}\right)$, that leads to local accumulation of this molecule near a cell-producent. It has been determined throughout 3D-mathematic modelling that the sphere of $\mathrm{H}_{2} \mathrm{~S}$ biological action is determined by that distance, at which metabolite's concentration is no less than $10 \%$ of its concentration in the place of synthesis, and is spread over 200 neighbouring cells per $1 \mathrm{sec}$ on the average [8]. Thus, $\mathrm{H}_{2} \mathrm{~S}$ acts as paracrine signaling molecule, but the distant effect is not excluded, because this metabolite is a part of blood plasma and may be transported by erythrocytes. It is determined that $\mathrm{H}_{2} \mathrm{~S}$ transport by human erythrocytes proceeds in 4 stages: 1) diffusion of $\mathrm{H}_{2} \mathrm{~S}$ throughout cell membranes or gas channels; 2) extracellular deprotonation of $\mathrm{H}_{2} \mathrm{~S}$ into HS; 3) arrival of HS- into erythrocyte throughout anion transporter - protein AE1 at the exchange for $\mathrm{Cl}^{-}$; 4) intracellular HS- protonation to $\mathrm{H}_{2} \mathrm{~S}$ [9]. The membrane transport of $\mathrm{H}_{2} \mathrm{~S}$ can also occur throughout aquaporins - water channels [10].

Biosynthesis of $\mathrm{H}_{2} \mathrm{~S}$. Major sources of endogenous $\mathrm{H}_{2} \mathrm{~S}$ in tissues are sulfur- containing amino acids - L-cysteine and L-homocysteine, which metabolized in reactions of transsulfuration and transamination with participation of pyridoxal 5 '-phosphate dependent enzymes of cystathionine $\gamma$-lyase (CSE, EC 4.4.1.1), cystathionine $\beta$-synthase (CBS, EC 4.2.1.22); 2) and cysteine aminotransferase (CAT, EC 2.6.1.3) (Table 1). Key reactions providing production of $\mathrm{H}_{2} \mathrm{~S}$ in tissues of animals and humans are as follows: 1) desulfuration of L-cysteine to pyruvate ( $\alpha, \beta$-elimination) by CSE; 2) condensation of L-homocysteine with L-cysteine ( $\beta$-replacement) and desulfuration of L-cysteine to L-serine ( $\beta$-elimination) by CBS; 3 ) transamination of L-cysteine with $\alpha$-ketoglutarate by CAT with production of 3-mercaptopyruvate, out of which $\mathrm{H}_{2} \mathrm{~S}$ is further emitted with participation of 3-mercaptopyruvate sulfur transferase (3-MST, EC 2.8.1.2). Cofactors of 3-MST in this reaction may be glutathione, thioredoxin and dihydrolipoic acid [11, 12].

Other ways of enzymatic $\mathrm{H}_{2} \mathrm{~S}$ synthesis were detected recently, physiologic meaning of which is not finally clarified (Table 2) [12-15]. Alternative sources of $\mathrm{H}_{2} \mathrm{~S}$ are pyridoxal 5'-phosphate dependent reactions: 1) desulfuration of L-cystine to L-thiocysteine with next $\mathrm{H}_{2} \mathrm{~S}$ releasing ( $\alpha, \beta$-elimination) by CSE; 2) desulfuration of L-cysteine to L-serine ( $\beta$-elimination) by CBS; 3 ) condensation of two molecules of L-homocysteine ( $\gamma$-replacement) to L-homolanthionine by CSE; 4) desulfuration of L-homocysteine to L-homoserine by CSE; 5) condensation of two molecules of L-cysteine ( $\beta$-replacement) to L-lanthionine with the participation of CSE or CBS; and also pyridoxal 5'-phosphate-independent reactions: 6) D-cysteine oxidation to 3-mercaptopyruvate by D-amino acid oxidase (DAAO, EC 1.4.3.3); 7) thiosulfate-anion reduction by thiosulfate-dithiol sulfurtransferase (TST, EC 2.8.1.5).

Kinetic parameters of key and alternative pyridoxal 5'-phosphate dependent reactions of $\mathrm{H}_{2} \mathrm{~S}$ synthesis, which have been studied in vitro on the example of human recombinant enzymes CSE and CBS, are significantly distinct. Investigations of Singh (2009) have shown that $96 \%$ of $\mathrm{H}_{2} \mathrm{~S}$ is produced in the condensation of L-cysteine with L-homocysteine with the participation of CBS with $V_{\max } 18.7 \mathrm{U} / \mathrm{mg}$ and $K_{\mathrm{m}} 3.2 \mathrm{mM}$. Alternative reactions of $\mathrm{H}_{2} \mathrm{~S}$ synthesis with the participation of CBS have such kinetic parameters: 1) desulfuration of L-cysteine into pyruvate with $V_{\max } 0.82 \mathrm{U} / \mathrm{mg}$ protein and $K_{\mathrm{m}} 27.3 \mathrm{mM}$; 2) lanthionine synthesis from L-cysteine with $V_{\max } 0.77 \mathrm{U} / \mathrm{mg}$ protein and $K_{\mathrm{m}} 45,6 \mathrm{mM}$ [13].

Chiku et al. have shown (2009) that among reactions of $\mathrm{H}_{2} \mathrm{~S}$ synthesis with the participation of CSE only cysteine desulfuration ( $\alpha, \beta$-elimination) can play the main role because its kinetic parameters are $V_{\text {max }} 0.6 \mathrm{U} / \mathrm{mg}$ protein and $K_{\mathrm{m}} 1.7 \mathrm{mM}$. It appeared that $K_{\mathrm{m}}$ of alternative CSE-dependent reactions of $\mathrm{H}_{2} \mathrm{~S}$ synthesis associated with lanthionine, homolanthionine and homoserine creation are significantly higher: $33 ; 5.9 ; 2.7 \mathrm{mM}$ at $V_{\max } 1.2 ; 6.6$; $1.2 \mathrm{U} / \mathrm{mg}$, respectively [14]. Kinetic parameters of $\mathrm{H}_{2} \mathrm{~S}$ synthesis from cystine are not determined, because under conditions close to physiological ones, the reaction does not proceed.

3-MST is pyridoxal 5'-phosphate-independent enzyme, which is functionally connected with CAT and, possibly, with TST. As opposed to CSE and CBS, for which $\mathrm{pH}$ 8.5-9.0 is optimal, 3-MST effectively synthesizes $\mathrm{H}_{2} \mathrm{~S}$ from 3-mercaptopyruvate at $\mathrm{pH}$ 7.4. This enzyme provides creation of persulfides, from which $\mathrm{H}_{2} \mathrm{~S}$ can release under interaction with thioles (gluthathione, dihydrolipoic acid, thioredoxin) [16, 17]. Also, 3-MST may turn sulfite- 
Ta ble 1. Key enzymatic reactions of $\mathrm{H}_{2} \mathrm{~S}$ creation in tissues of animals and humans

\begin{tabular}{|c|c|c|}
\hline Enzyme & Scheme of reaction & Ref. \\
\hline $\begin{array}{l}\text { Cystathionine } \\
\gamma \text {-lyase } \\
\text { (EC 4.4.1.1) }\end{array}$ & $\begin{array}{cc}\stackrel{\mathrm{COOH}}{\mid} \\
\mathrm{H}_{2} \mathrm{~N}-\underset{\mid}{\mathrm{C}}-\mathrm{H} \\
\mathrm{H}_{2} \mathrm{C}-\mathrm{SH} \\
\text { L-cysteine }\end{array}+\mathrm{H}_{2} \mathrm{O} \longrightarrow \underset{\mid}{\mathrm{COOH}}=\mathrm{O}+\mathrm{NH}_{3}+\mathrm{H}_{2} \mathrm{~S}$ & {$[13,14]$} \\
\hline $\begin{array}{l}\text { Cystathionine } \\
\beta \text {-synthase } \\
\text { (EC 4.2.1.22) }\end{array}$ & 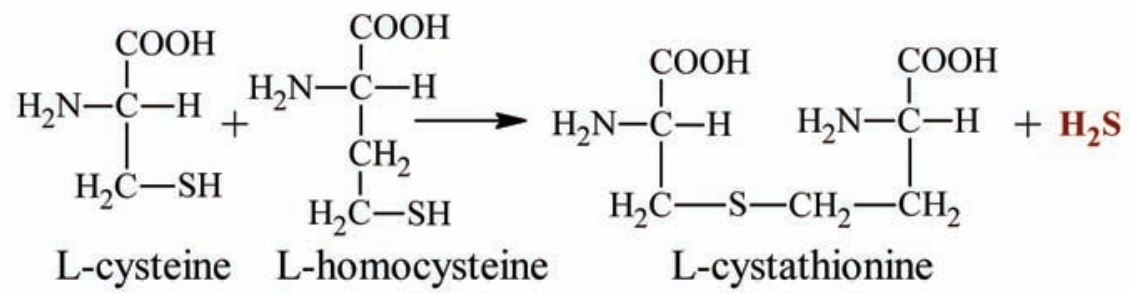 & {$[13,14]$} \\
\hline $\begin{array}{l}\text { Cysteine } \\
\text { aminotransferase } \\
\text { (EC 2.6.1.3) }\end{array}$ & 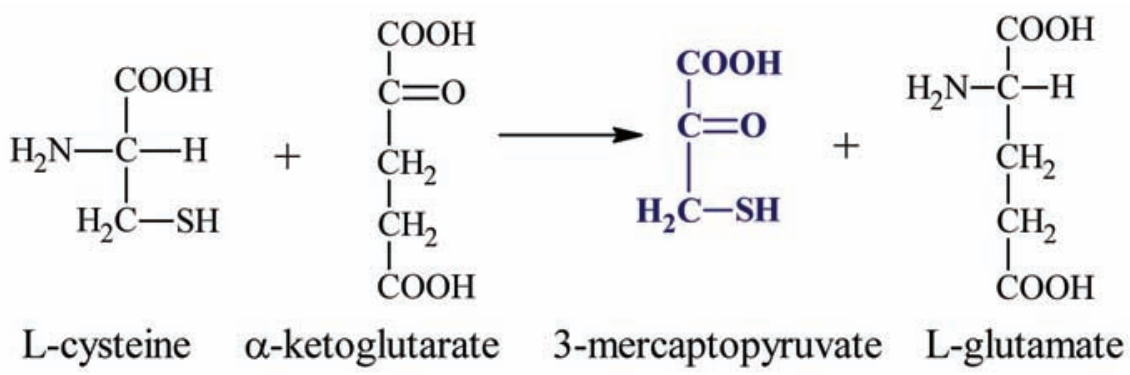 & {$[13,14]$} \\
\hline $\begin{array}{l}\text { 3-mercaptopyruvate } \\
\text { sulfur transferase } \\
\text { (EC 2.8.1.2) }\end{array}$ & 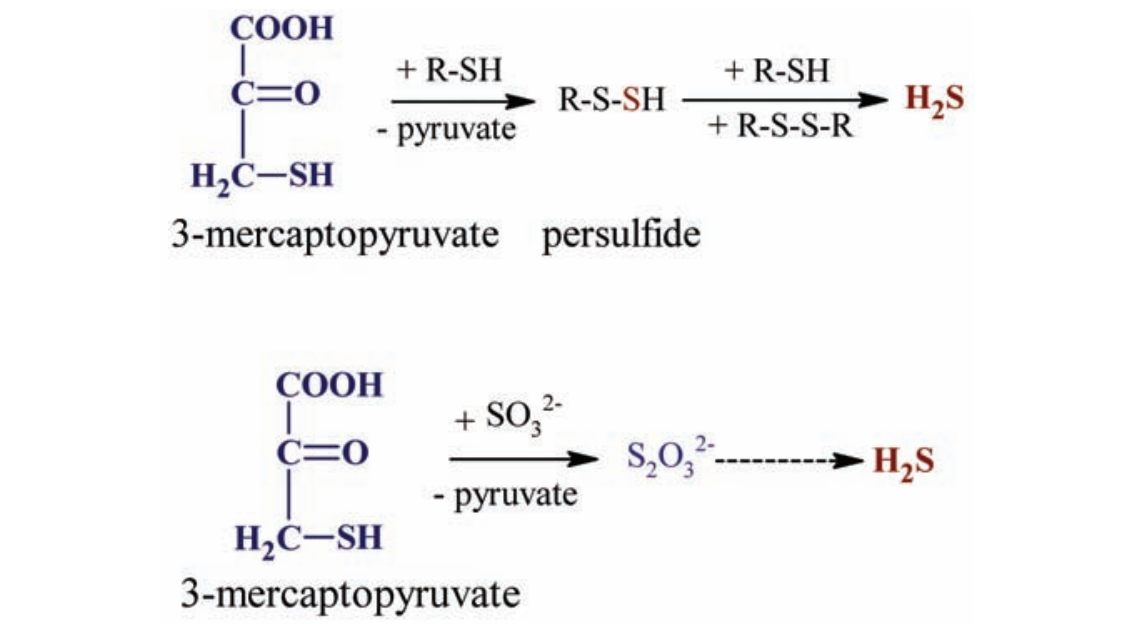 & {$[11,12]$} \\
\hline
\end{tabular}

anion into thiosulfite-anion, which is further reduced to $\mathrm{H}_{2} \mathrm{~S}$ with the participation of TST $[11,12,18]$.

The question is how $\mathrm{H}_{2} \mathrm{~S}$ general production may provide reactions, which necessitate significantly high substrate concentrations (L-cysteine and L-homocysteine). As it is known, under organizm conditions, the pull of free sulfur-containing amino acids is significantly lower, than that of their bound and disulfide forms. The content of general homocysteine in human blood plasma does not exceed
$15 \mu \mathrm{M}$, that of cysteine is $300 \mu \mathrm{M}$, but the content of their free (thiol) forms is about 0.13-0.17 and 24$27 \mu \mathrm{M}$, respectively [19]. Their quantity under pathology conditions may grow significantly: under homozygous deficit of CBS the level of general homocysteine in the blood plasm increases up to 100$500 \mu \mathrm{M}$ and above [20], the content of free cysteine may 60 times exceed the norm under chronic kidney failure. Part of free cysteine in blood plasma of pre-hemodialysis patients was $40.9 \%$ compared 
Ta ble 2. Alternative enzymatic reactions of $\mathrm{H}_{2} \mathrm{~S}$ creation in tissues of animals and humans

\begin{tabular}{|c|c|c|}
\hline Enzyme & Scheme of reaction & Ref. \\
\hline \multirow[t]{4}{*}{$\begin{array}{l}\text { Cystathionine } \\
\gamma \text {-lyase } \\
(\text { EC 4.4.1.1) }\end{array}$} & 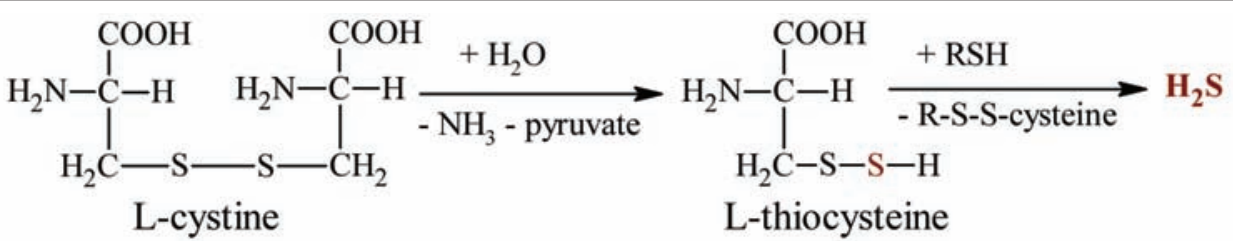 & {$[13,14]$} \\
\hline & 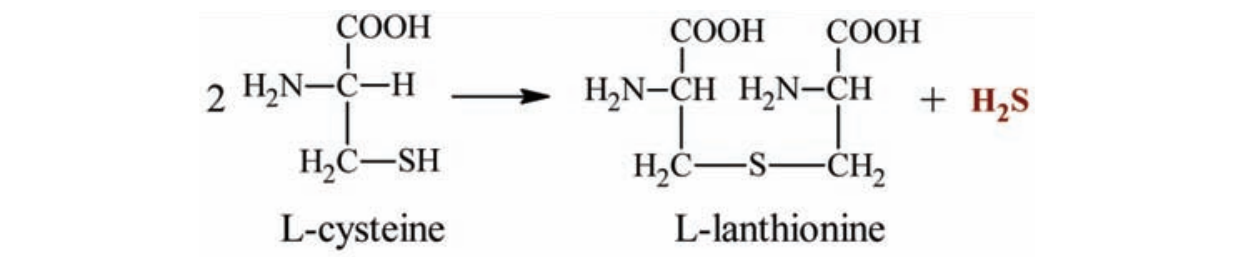 & {$[13,14]$} \\
\hline & 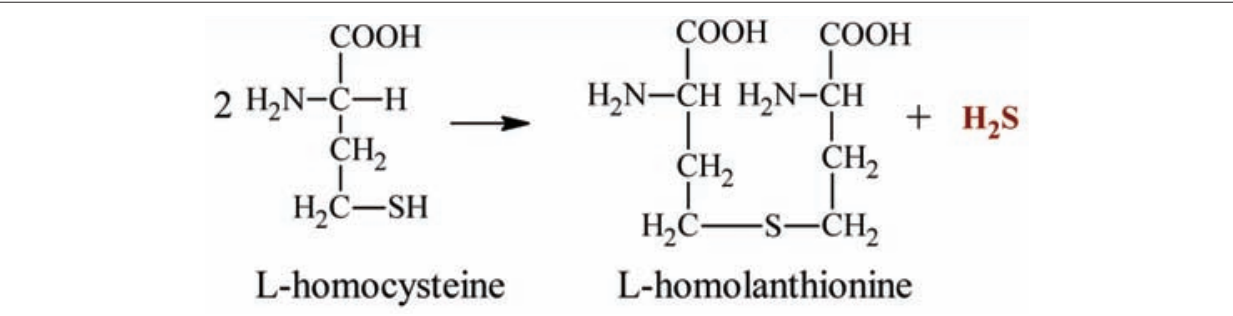 & {$[13,14]$} \\
\hline & 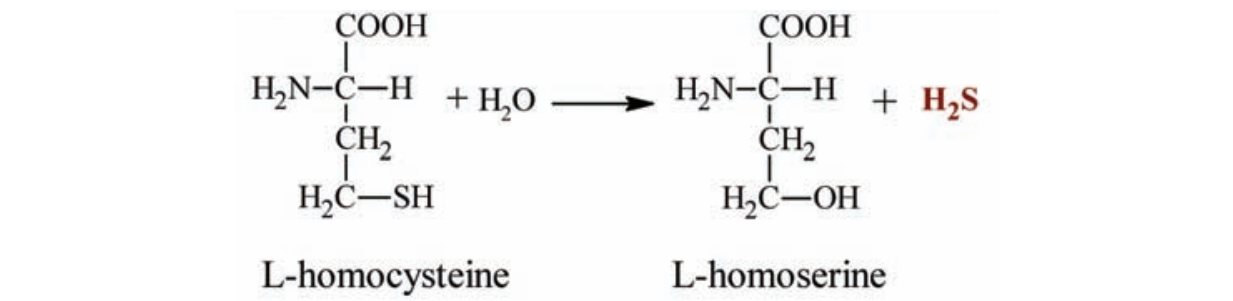 & {$[13,14]$} \\
\hline \multirow[t]{2}{*}{$\begin{array}{l}\text { Cystathionine } \\
\beta \text {-synthase } \\
\text { (EC 4.2.1.22) }\end{array}$} & 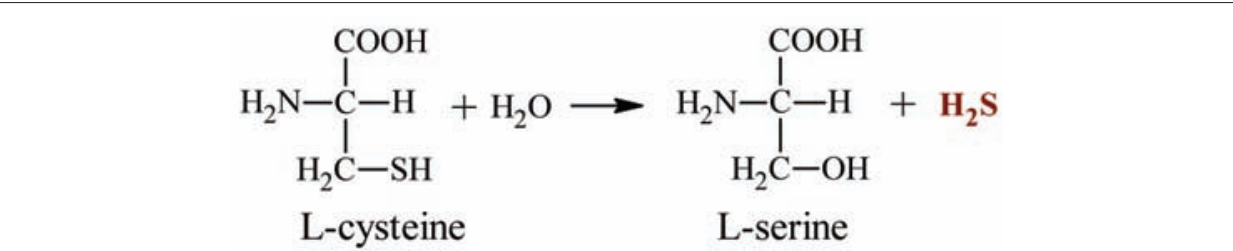 & {$[13,14]$} \\
\hline & 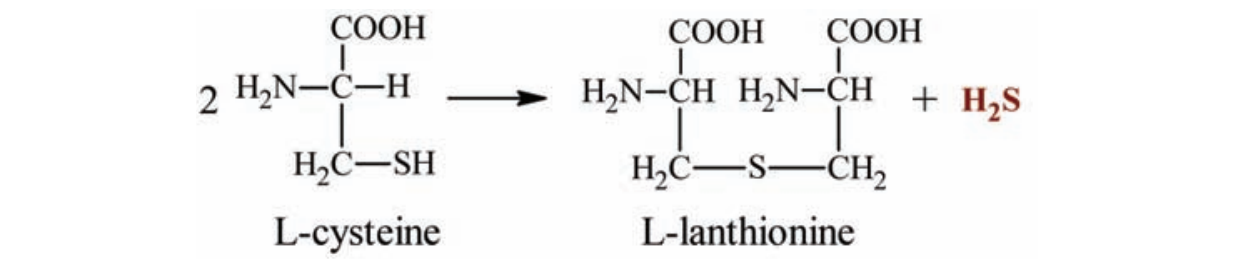 & {$[13,14]$} \\
\hline $\begin{array}{l}\text { D-amino acid } \\
\text { oxidase } \\
\text { (EC 1.4.3.3) }\end{array}$ & 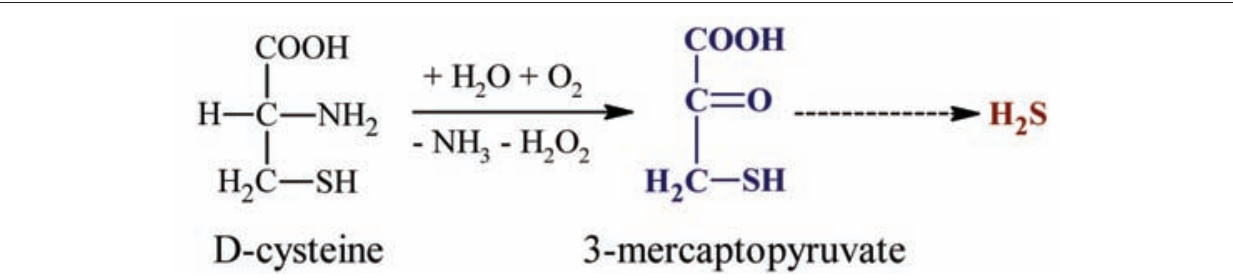 & [12] \\
\hline $\begin{array}{l}\text { Thiosulfate- } \\
\text { dithiol sulfurtrans- } \\
\text { ferase (EC 2.8.1.5) }\end{array}$ & $\mathrm{S}_{2} \mathrm{O}_{3}{ }^{2-}+2 \mathrm{R}-\mathrm{SH} \rightarrow \mathrm{SO}_{3}{ }^{2-}+\mathrm{R}-\mathrm{S}-\mathrm{S}-\mathrm{R}+\mathrm{H}_{2} \mathrm{~S}$ & {$[22,29]$} \\
\hline
\end{tabular}


to $1.6 \%$ in healthy persons [21]. Obviously, the role of alternative reactions of $\mathrm{H}_{2} \mathrm{~S}$ synthesis at ordinary concentrations of sulfur-containing amino acids in organism is insignificant, but it may increase under hyperhomocysteinemia or hypercysteinemia, which are often combined [19].

The role of pyridoxal phosphate-independent ways of $\mathrm{H}_{2} \mathrm{~S}$ creation (from D-cysteine and thiosulfate) in animal and human organism has not been studied completely. Studies of Shibuya and Kimura (2013) prove that optimal conditions for $\mathrm{H}_{2} \mathrm{~S}$ synthesis from D-cysteine exist in organism ( $\mathrm{pH}$ 7.4). However, this amino acid is not formed in the cells and may arrive only from exogenous sources [12]. The role of thiosulfate-anion and TST in creation of $\mathrm{H}_{2} \mathrm{~S}$ in tissues is the least studied. We have no clear data as of today regarding the content of thiosulfate-anion in organs and tissues, thus it is difficult to estimate the importance of this enzyme. Allowing for the concentration of thiosulfate-anion in blood plasma and urine of humans $(1.13 \pm 0.11 \mathrm{mg} / \mathrm{dl}$ and $0.28 \pm$ $0.02 \mathrm{mg} / \mathrm{dl}$, respectively) [22], the above-mentioned way of $\mathrm{H}_{2} \mathrm{~S}$ formation in tissues is possible.

Catabolism and deposition of $\mathrm{H}_{2} \mathrm{~S} . \mathrm{H}_{2} \mathrm{~S}$ catabolism may be performed by enzymatic and nonenzymatic ways (Table 3 ). In mytochodria HS- is oxidated to thiosulfate-anion and sulfite-anion by sulfide quinone oxido-reductase system (SQR). Then sulfite is converted to sulfate by sulfite oxidase (EC 1.8.3.1). SQR consists of three enzymes: thiosulfate:cyanide sulfur-transferase (rhodanese,
EC 2.8.1.1), sulfur dioxygenase (EC 1.13.11.18) and sulfide:quinone reductase (EC 1.8.5.4) [23]. $\mathrm{H}_{2} \mathrm{~S}$ may spontaneously react with mitochondrial hemoproteins - cytochrome oxidase and cytochrome $c$ with creation of sulfane sulfur $\left(\mathrm{S}^{0}\right)$ and reactive thiol radical (HS') [23, 24].

In cytosol $\mathrm{H}_{2} \mathrm{~S}$ methylates to methanethiol and dimethyl sulfide with participation of thiol S-methyltransferase (EC 2.1.1.9). Utilization of $\mathrm{H}_{2} \mathrm{~S}$ in erythrocytes proceeds in non-enzymatic way through formation of sulfhemoglobine [3, 2, 23].

$\mathrm{H}_{2} \mathrm{~S}$ catabolism by SQR and its direct reaction with thiols results in formation of unstable persulfides (R-S-S*-H, thiotaurine, thiocysteine) which contain active sulfane sulfur $\left(\mathrm{S}^{0}\right)$ [23]. $\mathrm{H}_{2} \mathrm{~S}$ is deposited in sulfane sulfur form in different tissues (brain, heart, liver, kidney) and can be released on demand. 3-MST and CAT provide $\mathrm{H}_{2} \mathrm{~S}$ deposition in polysulfides $[25,26]$. The quantity of polysulfides in cells with 3-MST and CAT expression is twice as much in comparison with cells without these enzymes [26].

$\mathrm{H}_{2} \mathrm{~S}$ participates in formation of nitrosothiols (RSNO) known as depot of NO in cells [27, 28]. HS Ta HS- may interact with active forms of nitrogen (NO', $\left.\mathrm{ONOO}^{-}\right)$with creation of the smallest nitrosothiol - thionitrous acid (HSNO) [27]. HSNO, however, reacts with thiols with formation of nitrosothiols and $\mathrm{H}_{2} \mathrm{~S}$ [27].

Features of $\mathrm{H}_{2} \mathrm{~S}$ tissue metabolism and its regulation. Organs and tissues are distinguished by the ability to produce $\mathrm{H}_{2} \mathrm{~S}$-synthesizing enzymes

Ta b le 3. Utilization and deponation of $\mathrm{H}_{2} \mathrm{~S}$ in tissues

\begin{tabular}{|c|c|c|}
\hline Enzyme & Scheme of reaction & Ref. \\
\hline $\begin{array}{l}\text { Sulfide:quinone reductase } \\
\text { (EC 1.8.5.4) }\end{array}$ & $\mathrm{H}_{2} \mathrm{~S}+\mathrm{R}-\mathrm{SH}+$ quinone $\rightarrow$ R-S-S $-\mathrm{H}+$ hydroquinone & [24] \\
\hline Sulfur dioxygenase (EC 1.13.11.18) & $\mathrm{R}-\mathrm{S}-\mathrm{S}^{*}-\mathrm{H}+\mathrm{O}_{2}+\mathrm{H} 2 \mathrm{O} \rightarrow \mathrm{R}-\mathrm{SH}+\mathrm{SO}_{3}^{2-}+2 \mathrm{H}^{+}$ & {$[23]$} \\
\hline $\begin{array}{l}\text { Thiosulfate:cyanide sulfur- } \\
\text { transferase (EC 2.8.1.1) }\end{array}$ & $\begin{array}{c}2 \mathbf{H S}^{-}+2 \mathrm{O}_{2} \rightarrow \mathrm{S}_{2} \mathbf{O}_{3}^{2-}+\mathrm{H}_{2} \mathrm{O} \\
\mathrm{S}_{2} \mathrm{O}_{3}^{2-}+\mathrm{CN}-\rightarrow \mathrm{SCN}^{-}+\mathbf{S O}_{3}{ }^{2-}\end{array}$ & {$[23]$} \\
\hline Sulfite oxidase (EC 1.8.3.1) & $\mathbf{S O}_{3}^{2-}+\mathrm{Fe}^{3+}($ cytochrome $c) \rightarrow \mathbf{S O}_{4}^{2-}+\mathrm{Fe}^{2+}($ cytochrome $c)$ & {$[3,23]$} \\
\hline $\begin{array}{l}\text { Thiol S-methyltransferase } \\
\text { (EC 2.1.1.9) }\end{array}$ & $\mathrm{H}_{2} \mathrm{~S} \rightarrow \mathrm{CH}_{3}-\mathrm{SH} \rightarrow \mathrm{CH}_{3}-\mathrm{S}-\mathrm{CH}_{3}$ & [23] \\
\hline Non-enzymatic way & $\begin{array}{c}\mathbf{H}_{2} \mathbf{S}+\text { methemoglobine } \rightarrow \text { sulfhemoglobine } \\
\text { HS }^{-}+\mathrm{Fe}^{3+}(\text { cytochrome } c) \rightarrow \mathrm{Fe}^{2+}(\text { cytochrome } c)+\mathbf{H S}^{\cdot}\end{array}$ & {$[23]$} \\
\hline Non-enzymatic way & $\begin{array}{c}\mathbf{H S}^{\cdot}+\mathrm{NO} \cdot \rightarrow \mathrm{HSNO} \\
\mathrm{HSNO}+\mathrm{RSH} \leftrightarrow \mathrm{RSNO}+\mathbf{H}_{2} \mathbf{S}\end{array}$ & {$[27,28]$} \\
\hline
\end{tabular}


and ability to produce $\mathrm{H}_{2} \mathrm{~S}$ (Table 4). In animal and human organism $\mathrm{H}_{2} \mathrm{~S}$ is formed in the liver where all $\mathrm{H}_{2} \mathrm{~S}$-synthesizing enzymes $(\mathrm{CBC}, \mathrm{CSE}, \mathrm{CAT}$, $3 \mathrm{MST})$ are expressed [5, 29-31]. Also $\mathrm{H}_{2} \mathrm{~S}$ is intensively formed in kidneys. CSE and CBS are expressed in renal cortex and medulla, proximal tubules, interstitial tissue [32], but 3-MST is expressed in glomerules [33].

CBS is considered the major producer of $\mathrm{H}_{2} \mathrm{~S}$ in the central nerve system; it is expressed in the hippocampus, cerebellum, cortex and brain stem $[5$, $15,34,35]$. Creation and deposition of $\mathrm{H}_{2} \mathrm{~S}$ as polysilfude in brain are provided by CAT and 3-MST, which are expressed in the cortex, cerebellum and retina [25]. CBS is localized in astrocytes, and 3-MST - in neurons [17]. Contribution of CSE to production of $\mathrm{H}_{2} \mathrm{~S}$ in brain is the least, however, this way is considered important in support of redox homeostasis of the brain [36]. CSE activity in the mice brain is about $1 \%$ of its activity in the liver. CSE is present in neurons of human brains and its activity is several times higher than that in mice [36].

In blood vessels $\mathrm{H}_{2} \mathrm{~S}$ is synthesized with participation of CSE which is mainly expressed in smooth myocytes, and with CAT/3-MST, which are expressed in endothelium. The expression of these enzymes has been found in the aorta, lung artery, mesenteric and kidney arteries $[3,5,11,17]$. CAT/3MST and CSE are expressed in the myocardium [37-39], but CAT/3-MST, CSE and CBS are expressed in skeletal muscles [40]. Considerably high ability of
$\mathrm{H}_{2} \mathrm{~S}$ creation was detected in the myometrium of rats and humans, in which CBS and CSE are expressed $[41,42]$. The expression of CSE and CBS is detected in the intestine, stomach, $\beta$-cells of pancreas [ $43-$ $45]$, adipocytes [46], lungs [47, 48].

$\mathrm{H}_{2} \mathrm{~S}$ synthesis regulation. CBS and CSE cells are localized in the cytozole, while 3-MST and $\mathrm{CAT}$ - in the mitochondria and cytozole (division of their fractions depends on tissue) [17, 26, 49].

Human and rat CBS is homotetramer and consists of 4 equal subunits with molecular weight of $63 \mathrm{kDa}$. Each subunit is bound to the cofactors pyridoxal 5'-phosphate, heme and S-adenosylmethionine [5]. S-adenosylmethionine is an allosteric activator of CBS. That is why CBS-dependent $\mathrm{H}_{2} \mathrm{~S}$ production may increase, if S-adenosylmethionine concentration is elevating in cells [1]. CBS activity is inhibited by $\mathrm{CO}$, which binds with high affinity with heme $\left(K_{\mathrm{i}} 5.6 \mu \mathrm{M}\right)$, and $\mathrm{NO}$ - only in high supraphysiological concentrations $\left(K_{\mathrm{i}} 360 \mu \mathrm{M}\right)$ [50]. One more mechanism of impact on CBS activity, which proves possible participation of enzyme in epigenetic regulation and gene expression, was detected recently. C-terminal fragment of CBS contains a tandem of two domains, which undergoes SUMO-modification (SUMO - small ubiquitin-like modifier) of lysine in position 211 that causes a decrease of enzyme's activity. CBS sumoylation is inhibited by cystathionine [51]. Biological importance of SUMO-modification of CBS remains unidentified so far. Hypothetically, such form of CBS translocation into nucleus with

Ta b le 4. Main $\mathrm{H}_{2} \mathrm{~S}$-synthesizing enzymes expression in laboratory animals and human tissues

\begin{tabular}{l|lc}
\hline \multicolumn{1}{c|}{ Organ, tissue } & \multicolumn{1}{c}{$\mathrm{H}_{2} \mathrm{~S}$-synthesizing enzymes } & Ref. \\
\hline Liver & $\mathrm{CSE}^{1,2,3}, \mathrm{CBS}^{1,2,3}, \mathrm{CAT}^{1}, 3-\mathrm{MST}^{1}$ & {$[5,29-31]$} \\
Kidneys & $\mathrm{CSE}^{1,2,3}, \mathrm{CBS}^{1,2,3}, \mathrm{CAT}^{1}, 3-\mathrm{MST}^{1}$ & {$[5,29,30,32,33,38]$} \\
Brain & $\mathrm{CBS}^{1,2,3}, 3-\mathrm{MST}^{1}, \mathrm{CSE}^{1,2,3}$ & {$[5,17,25,35,36]$} \\
Myocardium & $\mathrm{CSE}^{1,2}, 3-\mathrm{MST}^{1}$ & {$[37-39]$} \\
Aorta, endothelium & $\mathrm{CAT}^{1}, 3-\mathrm{MST}^{1}, \mathrm{CSE}^{2}$ & {$[5,11]$} \\
Aorta, smooth myocytes & $\mathrm{CSE}^{1}$ & {$[52,101]$} \\
Myometrium, placenta & $\mathrm{CBS}^{1}, \mathrm{CSE}^{1}$ & {$[41,42]$} \\
Skeletal muscles & $\mathrm{CSE}^{1}, \mathrm{CBS}^{1}, 3-\mathrm{MST}^{1}$ & {$[40]$} \\
Adipocytes & $\mathrm{CSE}^{1}$ & {$[46]$} \\
Stomach, intestine & $\mathrm{CBS}^{1,2}, \mathrm{CSE}^{12}$ & {$[43,78]$} \\
Pancreas, $\beta$-cells & $\mathrm{CBS}^{2}, \mathrm{CSE}^{2}$ & {$[45,44]$} \\
Lungs & $\mathrm{CSE}^{1,3}$ & {$[47,48]$} \\
\hline
\end{tabular}

Notation. Enzyme expression in ${ }^{1}$ rat (Rattus norvegicus), ${ }^{2}$ mouse (Mus musculus) and ${ }^{3}$ human tissues 
further desumoylation and renovation of ability to $\mathrm{H}_{2} \mathrm{~S}$ synthesis can take place [51].

$\mathrm{H}_{2} \mathrm{~S}$ formation by CSE is activated under the action of calmodulin in the presence of $1-2 \mathrm{mM} \mathrm{Ca}^{2+}$ [52]. However, basic concentration of $\mathrm{Ca}^{2+}$ in cells is around $100 \mathrm{nM}$, that is why the role of $\mathrm{Ca}^{2+} / \mathrm{calmo}^{-}$ dulin in regulation of CSE-dependent $\mathrm{H}_{2} \mathrm{~S}$ production necessitates further study [6]. Under in vitro conditions the ability of recombinant human CSE to sumoylation is established, and this process is not blocked by cystathionine [51]. Whether SUMOmodification of CSE under conditions of organism exists and what kind of role this process plays has not been determined yet. Under hypoxia when concentration of cytosolic $\mathrm{Ca}^{2+}$ increases, CSE translocation from cytosole to mitochondrium may happen, the process is accompanied by the increase of mitochondrial $\mathrm{H}_{2} \mathrm{~S}$ production and ATP synthesis [26].

In contrast to CSE, $\mathrm{H}_{2} \mathrm{~S}$ formation with participation of CAT/3-MST is dose-dependently inhibited by $\mathrm{Ca}^{2+}$ (with full blocking in the presence of $2.9 \mu \mathrm{M}$ $\mathrm{Ca}^{2+}$ ) and does not depend on calmodulin [17]. CAT activity decreases with $\mathrm{L}$-aspartate increase in the medium [49]. 3-MST-dependent $\mathrm{H}_{2} \mathrm{~S}$ production increases with the increase of thioredoxin and dihydrolipoic acid content in cells [17].

Concentration of endogenous $\mathrm{H}_{2} \mathrm{~S} . \mathrm{H}_{2} \mathrm{~S}$ content in blood plasma of animals (rats) and humans is around $50-80 \mu \mathrm{M}[2,3,53] . \mathrm{H}_{2} \mathrm{~S}$ presence is more considerable in tissues, in particular, the content of this metabolite in the animal brain is around 50$160 \mu \mathrm{M}[17,2]$. According to other data, $\mathrm{H}_{2} \mathrm{~S}$ content in the brain, myocardium and kidneys of rats is $2.6 ; 11.4$ and $6.7 \mu \mathrm{g} / \mathrm{g}$ of tissue, respectively [54]. We have to mention that measurement of $\mathrm{H}_{2} \mathrm{~S}$ content in tissues in the majority of investigations is performed by colorimetric method (in compliance with the reaction with N,N-dimethyl-p-phenylenediamine in the presence of $\mathrm{FeCl}_{3}$ ), which needs highly acidic medium and does not exclude $\mathrm{H}_{2} \mathrm{~S}$ release from the tissue depot. Presumably, intracellular free $\mathrm{H}_{2} \mathrm{~S}$ concentration is much more less, because $\mathrm{pH}$ is around 7-8 in the mitochondria. Free $\mathrm{H}_{2} \mathrm{~S}$ concentration determined by the method of gas chromatography, was $0.12 \mu \mathrm{mol} / \mathrm{kg}$ of protein $(14 \mathrm{nM})$ in the rat brain, and concentration of acid-labile sulfur was $916 \mu \mathrm{mol} / \mathrm{kg}$ of protein [55].

According to the results of our own studies (Table 5), general $\mathrm{H}_{2} \mathrm{~S}$ content and specific activity of $\mathrm{H}_{2} \mathrm{~S}$-synsethizing enzymes in rats' tissues are on the highest level in the liver and kidneys, slightly lower in myocardium, brain and aorta. Determination of $\mathrm{H}_{2} \mathrm{~S}$ content and production in tissues was performed as it has been described [22, 56-58].

\section{$\mathrm{H}_{2} \mathrm{~S}$ biological role and molecular targets.}

$\mathrm{H}_{2} \mathrm{~S}$ in organism plays a role of signaling molecule, gasotransmitter; no specific receptors have been found for it. Different ion channels, receptors, enzymes and proteins, regulating numerous biochemical and physiological processes, play a role of $\mathrm{H}_{2} \mathrm{~S}$ molecular targets (Table 6).

A key mechanism of $\mathrm{H}_{2} \mathrm{~S}$-signaling is S-sulfhydration of proteins, post-translation modification with convertation of -SH groups into -SSH, which significantly increases reactivity of cysteine residues and increases functional activity of molecular targets as well $[6,17,59] . \mathrm{H}_{2} \mathrm{~S}$ also reduces disulfide bonds of cystine residues with -SH groups releasing [23]. Redox-modification of proteins with participation of $\mathrm{H}_{2} \mathrm{~S}$ may be of independent regulatory importance as well as serve as a preparatory stage for S-sulfhydration and other kinds of post-translational S-modification (S-nitrosylation, S-homocysteinylation, S-glutathionylation). For example, activation of NMDA-receptors with participation of $\mathrm{H}_{2} \mathrm{~S}$ proceeds in two stages: 1) NMDA-receptors become active under reduction of their disulfide form into thiol form, 2) transition of thiol form into persulfide form

Ta ble 5. $\mathrm{H}_{2} \mathrm{~S}$ content and activity of $\mathrm{H}_{2} S$-synthesizing enzymes in rats' organs $(M \pm m, n=10)$

\begin{tabular}{l|c|c|c|c|c}
\hline \multirow{2}{*}{ Organ, tissue } & \multirow{2}{*}{$\begin{array}{l}\mathrm{H}_{2} \mathrm{~S}, \mathrm{nmol} / \\
\text { mg protein }\end{array}$} & \multicolumn{4}{|c}{ Enzyme activity, nmol $\mathrm{H}_{2} \mathrm{~S} /$ min $\cdot \mathrm{mg}$ protein } \\
\cline { 3 - 6 } & & $\mathrm{CSE}$ & $\mathrm{CBS}$ & $\mathrm{CAT} / 3-\mathrm{MST}$ & $\mathrm{TST}$ \\
\hline Liver & $3.85 \pm 0.21$ & $3.09 \pm 0.15$ & $2.75 \pm 0.18$ & $2.47 \pm 0.10$ & $13.0 \pm 0.55$ \\
Kidneys & $3.27 \pm 0.16$ & $1.65 \pm 0.11$ & $2.17 \pm 0.14$ & $2.49 \pm 0.18$ & $3.29 \pm 0.14$ \\
Brain & $1.52 \pm 0.08$ & $0.27 \pm 0.03$ & $0.57 \pm 0.03$ & $0.13 \pm 0.03$ & $1.25 \pm 0.08$ \\
Myocardium & $2.37 \pm 0.10$ & $0.23 \pm 0.03$ & 0 & $0.52 \pm 0.07$ & $1.20 \pm 0.06$ \\
Aorta & $1.28 \pm 0,06$ & $0.67 \pm 0.04$ & 0 & $0.59 \pm 0.05$ & $1.98 \pm 0.08$ \\
\hline
\end{tabular}


Ta ble 6. $\mathrm{H}_{2} \mathrm{~S}$-signaling: mechanism, targets, biological processes

\begin{tabular}{|c|c|c|c|}
\hline Mechanisms & Molecular targets & Target cells & Biological processes \\
\hline 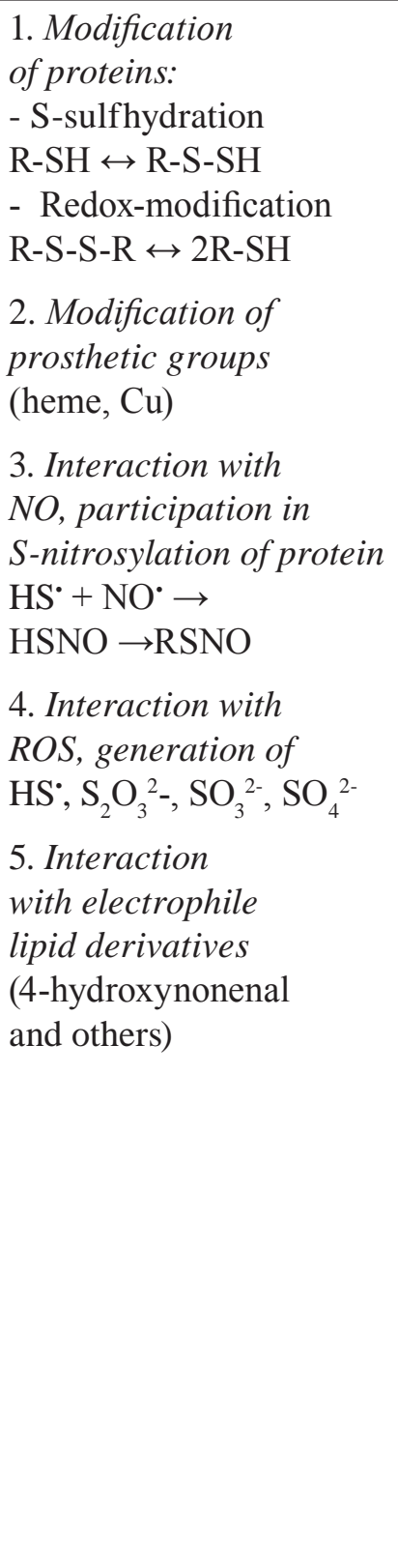 & $\begin{array}{l}\text { Ion channels: } \\
\text { - } \mathrm{K}^{+} \text {-ATP-channels } \\
\text { - } \mathrm{K}^{+}\left(\mathrm{Ca}^{2+}\right) \text {-channels } \\
\text { - T- or L-type of } \\
\mathrm{Ca}^{2+} \text {-channels } \\
\text { - TRP- channels } \\
\left.\text { (TRPV }_{1}, \mathrm{TRPA}_{1}\right) \\
\text { - Cl--channels } \\
\text { Receptors: } \\
\text { NMDA receptors } \\
\text { Signaling enzymes, } \\
\text { transcription factors: } \\
\text { adenylate cyclase } \\
\text { protein kinase A } \\
\text { protein kinase C } \\
\text { protein kinase B (Akt) } \\
\text { phosphoinositide } \\
\text { 3-kinase (PI3K) } \\
\text { phosphodiesterase } \\
\text { MAPK, ERK } \\
\text { NF- } \beta, \text { Nrf2, HIF-1 } \alpha \\
\text { Others: } \\
\text { glyceraldehyde-3- } \\
\text { phosphate dehydrogenase } \\
\text { glutamate-cysteine ligase } \\
\text { thioredoxin reductase } \\
\text { cytochrome } c \text { oxidase } \\
\text { cytochrome } c \\
\text { monoamine oxidase } \\
\text { actin, } \beta \text {-tubulin } \\
\text { cystine/glutamate } \\
\text { antiporters } \\
\text { excitatory amino } \\
\text { acid transporters }\end{array}$ & $\begin{array}{l}\text { neurons } \\
\text { astrocytes } \\
\text { smooth myocytes } \\
\text { cardiomyocytes } \\
\text { skeletal myocytes } \\
\text { pancreatic } \beta \text {-cells } \\
\text { endothelium } \\
\text { hepatocytes } \\
\text { platelets } \\
\text { leukocytes } \\
\text { renal tubular epithelium } \\
\text { gastrointestinal } \\
\text { epithelium }\end{array}$ & $\begin{array}{l}\text { neurotransmission } \\
\text { nociception } \\
\text { vascular tone regulation } \\
\text { myocardial contractility } \\
\text { cytoprotection } \\
\text { inflammation } \\
\text { apoptosis } \\
\text { angiogenesis } \\
\text { platelet aggregation } \\
\text { insulin secretion } \\
\text { cysteine transport } \\
\text { into cells } \\
\text { glutathione synthesis } \\
\text { tissue respiration } \\
\text { aging } \\
\text { circadian rhythm } \\
\text { gastroduodenal motility }\end{array}$ \\
\hline
\end{tabular}

(S-sulfhydration) with a further, more considerable increase of NMDA-receptors activity [17].

Mustafa et al. (2009) obtained direct proofs that S-sulfhydration raises the activity of ATP-sensitive potassium channels (-SSH modification of Kir6,1 subunit), glyceraldehyde-3-phosphate dehydrogenase (-SSH modification Cys150) and increases actin ability to polymerization [59]. S-sulfhydration increases neuroprotective activity of ubiquitin E3 ligase [15]. $\mathrm{H}_{2} \mathrm{~S}$ impact over other molecular targets, calcium channels of different types, TRP (transient receptor potential) channels $\left(\mathrm{TRPV}_{1}, \mathrm{TRPA}_{1}\right)$, protein kinases, factors of transcription, is going on presumably through S-sulfhydration/ desulfhydration. This is proved by the results of numerous studies in vivo and in vitro with usage of $\mathrm{H}_{2} \mathrm{~S}$ donors (NaHS), inhibitors of $\mathrm{H}_{2} \mathrm{~S}$-synthesizing enzymes, knock-out of CSE and CBS genes in animals.

$\mathrm{H}_{2} \mathrm{~S}$ together with NO participates in S-nitrosylation of proteins and low-molecular thiols $[28,27]$. S-nitrosylation, in contrast to S-sulfhydration, decreases cystein's ability to reaction and leads 
to further lost of activity of molecular targets. [6, $17,59]$. For example, glyceraldehyde-3-phosphate dehydrogenase is inactivated during S-nitrozylation Cys150 [59]. $\mathrm{H}_{2} \mathrm{~S}$, in its turn, may express NO, activating guanilate cyclase and its own signaling ways, from nitrosothiols [27, 28].

$\mathrm{H}_{2} \mathrm{~S}$ also acts through interaction with prosthetic groups of metalloproteins, reactive oxygen species (ROS), low-molecular electrophilic derivatives. $\mathrm{H}_{2} \mathrm{~S}$ in high concentrations blocks the activity of cytochrome $c$ oxidase, reducing by electrons heme $a a 3, C u B$ and cytochrome $c$ [23]. $\mathrm{H}_{2} \mathrm{~S}$ may reduce $\mathrm{Fe}^{3+}$ into $\mathrm{Fe}^{2+}$ of methemoglobin with its conversion into a form able to bind and transport oxygen [23]. Under $\mathrm{H}_{2} \mathrm{~S}$ interaction with ROS, generation of thiyl radical and thiosulfate anion which is transformed into oxygen-containing sulfur derivatives (sulfites and sulfates) is going on. It is not excluded that this way also mediates $\mathrm{H}_{2} \mathrm{~S}$ signaling, because $\mathrm{SO}_{2}$ participates in regulation of vascular tonus and contraction of the myocardium [60]. It is proved that $\mathrm{Na}_{2} \mathrm{SO}_{3} / \mathrm{NaHSO}_{3}$ causes dose-dependent relaxation of isolated rings of rats' aorta in vitro [61]. As a nucleophile, $\mathrm{H}_{2} \mathrm{~S}$ easily interacts with electrophile lipid derivatives, including 4-hydroxynonenal, which is a strong modulator of oxidative stress, cell proliferation, apoptosis [62].

Biological effect of $\mathrm{H}_{2} \mathrm{~S}$ may be significantly distinct depending on tissue localization of molecular target. $\mathrm{H}_{2} \mathrm{~S}$ impact on ion channels, for example, is going on in such directions $[7,15,26,63$, 64]: 1) activation of ATP-K $\mathrm{K}^{+}$-channels of smooth myocytes of blood vessels, that is associated with vasodilation, lowering of arterial pressure, cardioprotection under ischemia/reperfusion, inhibition of insulin secretion by the $\beta$-cells, anti-inflammatory, antinociceptive and anti-apoptosis effects; 2) inhibition of $\mathrm{Ca}^{2+}$-channels of L-type in cardiomyocytes (with $\mathrm{Ca}^{2+}$ level decrease) and their activation in neurons (with an increase of $\mathrm{Ca}^{2+}$ level); inhibition of large $\mathrm{K}^{+}\left(\mathrm{Ca}^{2+}\right)$-channels in carotide sinuses and their activation in pituitary cells; 3) activation of $\mathrm{Ca}^{2+}$-channels of T-type and TRPV ${ }_{1}$ channels, that is associated with $\mathrm{H}_{2} \mathrm{~S}$-induced hyperalgesia and pronociceptive effect; activation of TRPA - -channels with transportation of $\mathrm{Ca}^{2+}$ into astrocytes; 4) $\mathrm{H}_{2} \mathrm{~S}$ induced contraction of out-vascular smooth muscles and increase $\mathrm{Cl}^{-}$secretion in gastrointestinal tract are connected with activation of TRPV ${ }_{1}$ and TRPA channels; 5) $\mathrm{Cl}^{-}$channels activation and prevention from neurons oxytosis.
Year after year more and more mechanisms of $\mathrm{H}_{2} \mathrm{~S}$-signaling are identified, where kinases, transcription factors, growth factors and other regulator molecules are involved. $\mathrm{H}_{2} \mathrm{~S}$ action may be mediated through:

1) modulation of adenylate cyclase, phosphodiesterase activity and cAMP content in cells;

$\mathrm{H}_{2} \mathrm{~S}$ causes inhibition of adenylate cyclase and decrease of cAMP content in neurons of morphindependent mice [65]; phosphodiesterase activity increase in juxtaglomerulal cells of rats' kidneys with renovascular hypertension [66]; cAMP level and activity of protein kinase A increase but cAMPdependent phosphodiesterase activity decrease in isolated mitochondria of rats' hepatocytes [67]; cAMP synthesis increase in culture of neurons and glial cells [68].

2) modulation of protein kinases C, PI3K, B (Akt), MAPK, ERK activity;

$\mathrm{H}_{2} \mathrm{~S}$ induces an increase of activity and expression of protein kinase C [69]; phosphoinositide 3-kinase (PI3K), protein kinaseB (p-Akt), kinase$3 \beta$ glycogen synthetase (GSK-3 $\beta$ ) and protein Bcl-2 [70]; inhibits expression of mitogen-activated protein kinase (MAPK) and extracellular signal-regulated kinases (ERK) [4, 71], that decreases inflammatory response and disorder of cells under action of different factors.

3) modulation of activity of transcription factors Nrf2, NF- $\kappa$ B, HIF-1 $\alpha$;

$\mathrm{H}_{2} \mathrm{~S}$ stimulates translocation in the nucleus of Nrf2 - nuclear factor (erythroid-derived nuclear factor of transcription), that activates antioxidant response pathway and up-regulates thioredoxin reductase, glutathione S-transferase, thioredoxin-1 expression [23] and glutathione synthesis [72]; inhibits NF- $\mathrm{KB}$ expression (nuclear factor kappaB) and down-regulates proinflammatory cytokines expression [73, 74]; up-regulates expression of HIF-1 $\alpha$ (hypoxia-inducible factor-1) and vascular endothelial growth factor (VEGF), which stimulates angiogenesis [23].

4) modulation of $\mathrm{NO}$ and $\mathrm{CO}$ synthesis and their signaling pathways;

$\mathrm{H}_{2} \mathrm{~S}$ up-regulates eNOS expression and increases endothelial NO production [23]; decreases iNOS production and nitrosative stress [75]; up-regulates heme oxygenase- 1 expression and $\mathrm{CO}$ production in cardiomyocytes and other cells $[75,76]$.

5 ) impact on aging and circadian rythm genes (SIRT1, Klotho) expression, through which formation of age-associated changes in tissues is mediated [77]. 
Workers of Blood Circulation Physiology Department of the O. O. Bohomolets Institute of Physiology of NAS of Ukraine (Kyiv) under leadership of V. F. Sahach, Corresponding Member of NAS of Ukraine, doctor of medical science, assessed that $\mathrm{H}_{2} \mathrm{~S}$ is involved into opening of mitochondrial permeability transition pore, which is a key player in development of apoptosis and necrosis, and this effect is realized through $\mathrm{K}^{+}$-ATP-channels modulation [102-104].

Direction of $\mathrm{H}_{2} \mathrm{~S}$ action depends on its content in tissues. At low (physiological) concentrations $\mathrm{H}_{2} \mathrm{~S}$ shows its vasodilating, cytoprotector, antioxidant, anti-inflammatory and anti-apoptotic effects. It also increases sensibility of NMDA-receptors of neurons to glutamate, stimulates $\mathrm{Ca}^{2+}$ transportation to astrocytes and increases synaptic activity. $\mathrm{H}_{2} \mathrm{~S}$ activates cystine-glutamate antiporters, stimulates transportation of cysteine into mitochondria, and increases activity of $\boldsymbol{\gamma}$-glutamylcysteine synthetase (glutamatecysteine ligase, EC 6.3.2.2) and glutathione synthesis in neurons and other cells $[4,17,23,26,68] . \mathrm{H}_{2} \mathrm{~S}$ in supraphysiological and toxic concentration induces mithohondrial dysfunction, blocks tissue respiration and oxidative phosphorylation, increases vascular tonus, causes hyperalgesia, promotes inflammation and apoptosis, inhibits synaptic transmission. $\mathrm{H}_{2} \mathrm{~S}$ enables biogen amins effects $(\gamma$-aminobutiric acid, glutamate, serotonin, dophamine, epinephrine and norepinephrine) and acetylcholine by up-regulation of their receptors exression and inhibition of monoamine oxidase and acetylcholine esterase activity $[17,68]$. Low $\mathrm{H}_{2} \mathrm{~S}$ concentrations increase basal tension, smooth muscle contractions and motility of the gastric antrum, but high $\mathrm{H}_{2} \mathrm{~S}$ concentrations, on the contrary, decrease all the above-mentioned functions [78]. $\mathrm{H}_{2} \mathrm{~S}$ in concentration of $0.1-1 \mu \mathrm{M}$ increased electron transport and ATP content, and being in a concentration of 3-30 $\mu \mathrm{M}$ it inhibited cytochrome $c$ oxidase and oxidative phosphorylation in mitochondria of isolated hepatocytes [79].

Different pathological conditions are associated with disorder of $\mathrm{H}_{2} \mathrm{~S}$ content in tissues. A decrease of basic $\mathrm{H}_{2} \mathrm{~S}$ content in blood plasma is noticed in patients with arterial hypertension, ischaemic heart disease, deep venous thrombosis, Alzheimer's disease, hyperhomocysteinemia $[3,19,53]$. An increase of $\mathrm{H}_{2} \mathrm{~S}$ content is observed in patients with Down's syndrome, with decompensated liver cirrhosis, sepsis, ischaemic stroke, chronic obstructive pulmonary diseases $[19,3]$.
$\mathrm{H}_{2} \mathrm{~S}$ metabolism modulators in biology and medicine. The following basic approaches are used to study $\mathrm{H}_{2} \mathrm{~S}$ role in vivo and in vitro: 1) introduction of inorganic and organic $\mathrm{H}_{2} \mathrm{~S}$ donors; 2) introduction of specific inhibitors of $\mathrm{H}_{2} \mathrm{~S}$-synthesizing enzymes; 3) modification of efficiency and toxicity of pharmacological remedies with the help of $\mathrm{H}_{2} \mathrm{~S} ; 4$ ) modification of $\mathrm{H}_{2} \mathrm{~S}$ metabolism with the help of pharmacological drugs. Examples of some $\mathrm{H}_{2} \mathrm{~S}$ metabolism modulators are presented in Table 7.

$\mathrm{H}_{2} \mathrm{~S}$ under conditions of organism generally works in the form of HS-, that is why NaHS or $\mathrm{Na}_{2} \mathrm{~S}$ are used as its donors. Information on doses, ways and duration of administration to animals of inorganic $\mathrm{H}_{2} \mathrm{~S}$ donors varies [80]. $\mathrm{NaHS} / \mathrm{Na}_{2} \mathrm{~S}$, according to most studies, are injected parenterally (intraperitoneally, intravenously) in doses from $100 \mu \mathrm{g} / \mathrm{kg}$ to $3 \mathrm{mg} / \mathrm{kg}$ of the animal body weight, and duration of experiment may vary from several hours to 2-3 weeks [80]. In long-term studies (8-10 weeks) NaHS is added to drinking water in concentrations of about $30 \mu \mathrm{mol} / 1$; animals drink it ad libitum [81]. We should note that $\mathrm{LD}_{50}$ for NaHS under parenteral injection is $14.6 \pm 1.0 \mathrm{mg} / \mathrm{kg}$ [82], in compliance with other data it is $60.2 \mathrm{mg} / \mathrm{kg}$, and conventionally therapeutic doses of NaHS are about $1 / 20 \mathrm{LD}_{50}$ [83]. $\mathrm{NaHS} / \mathrm{Na}_{2} \mathrm{~S}$ in such concentration range decrease the ischaemic-reperfusion damages under conditions of myocardial infarction, kidney ischemia, intestinal ischemia, show antioxidative, cerebroprotective, antiinflammatory features $[7,17,34,68,80,81]$.

Vasodilatory, cytoprotective, antioxidative, anti-inflammatory effects of $\mathrm{NaHS} / \mathrm{Na}_{2} \mathrm{~S}$ in studies in vitro are realized in broader range concentrations from 1 to $1000 \mu \mathrm{M}$ [80].

We have shown that $\mathrm{H}_{2} \mathrm{~S}$ donors demonstrate antiaggregation and anticoagulant effect: NaHS in concentration of $1 \mathrm{mM}$ inhibited aggregation of human platelets, induced by ADP and collagen, and decreased amidolytic activity of thrombin $\left(\mathrm{IC}_{50}=65.3 \pm 3.76 \mu \mathrm{M}\right)$ in vitro; the injection of $\mathrm{Na}_{2} \mathrm{~S} \cdot 9 \mathrm{H}_{2} \mathrm{O}$ (Sigma, USA) to rats in the amount of $3.36 \mathrm{mg} / \mathrm{kg}$ once a day during 7 days caused the increase of prothrombin time and activated partial thromboplastic time and decrease of Xa factor activity [19]. According to data of Nishikawa et al. (2013), NaHS inhibits thrombocyte aggregation, induced by ADP and collagen in plasma enriched by thrombocytes in concentrations of $0.1-0.3 \mathrm{mM}$, and in a suspension of washed up thrombocytes of rabbits in concentrations of 1-3 mM, respectively [84]. 
Table 7. Examples of $\mathrm{H}_{2} \mathrm{~S}$ metabolism modulators

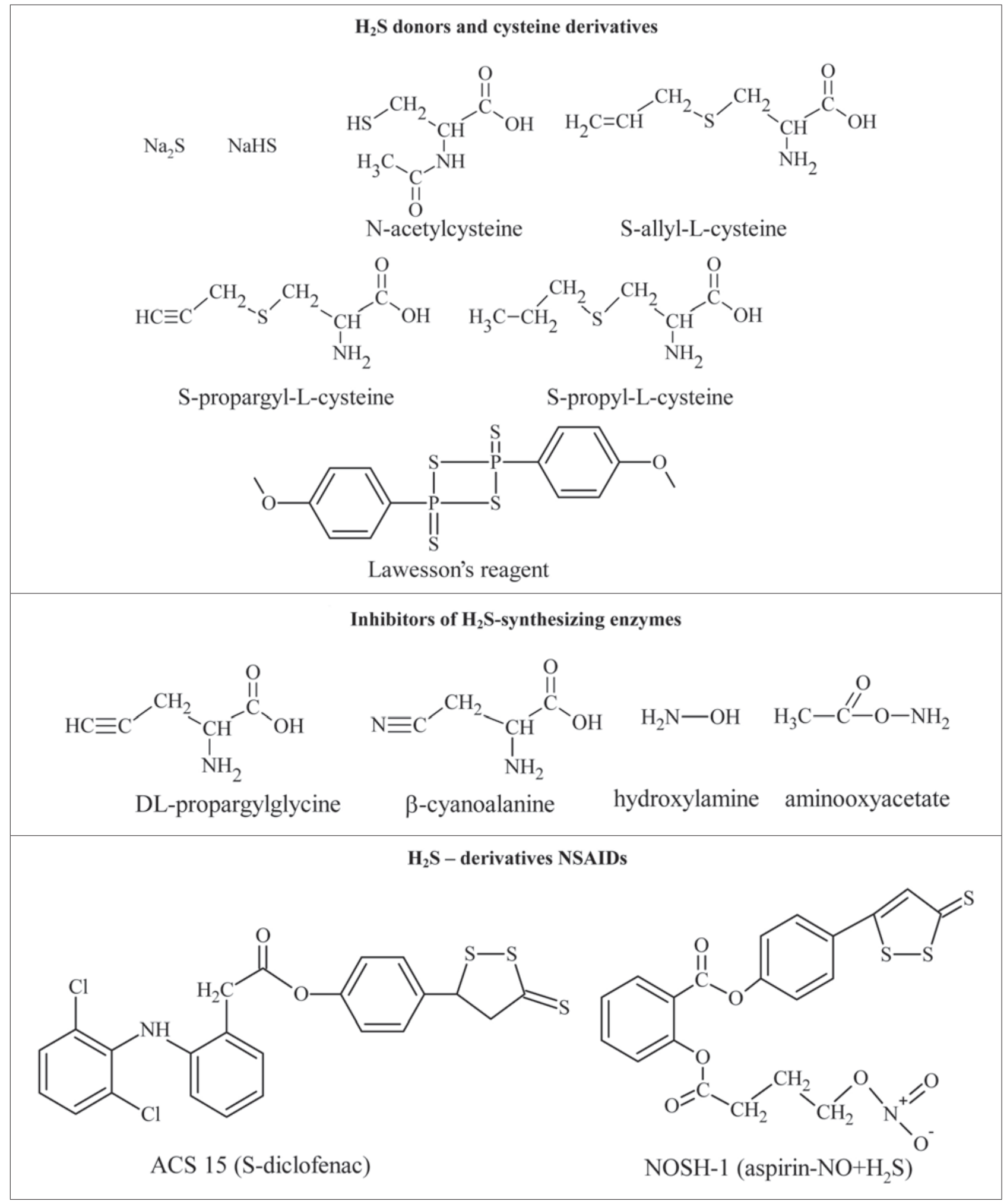

It has been showed in works of N. A. Strutynska, O. M. Semenykhina et al $(2011,2013)$ that NaHS та L-cystein in physiological concentrations improve functional conditions of mitochondria in the heart, prevent $\mathrm{Ca}^{2+}$-induced opening of mitochondrial pore and swelling of mitochondria at the time when CSE inhibitor propargylglycine increases sensitivity of mitochondria pore up to the action of $\mathrm{Ca}^{2+}$ inductor 
and causes mitochondria swelling [102-104]. Gradual swelling of rats' heart's mitochondria is observed in potassium-free medium in the presence of NaHS in concentrations of $10^{-12}-10^{-8} \mathrm{M}$ [102]. Age distinctions regarding $\mathrm{H}_{2} \mathrm{~S}$ impact over pore creation in the heart mitochondria have been observed: NaHS protector effect in adult rats is realized in a more broad range of concentrations $\left(10^{-6}, 10^{-5}\right.$ and $\left.5 \cdot 10^{-5} \mathrm{M}\right)$ than in old rats $\left(10^{-5} \mathrm{M}\right)$ [102]. NaHS in the range of concentrations $10^{-9}-10^{-6} \mathrm{M}$ causes dose-depending decrease of oxygen absorption by isolated mitochondria of adult rats' heart in the presence of succinate and ADP at concentration of $10^{9}$ and $10^{-8} \mathrm{M}$ and increases connection between oxidation and phosphorylation [103]. Preincubation of isolated mitochondria with inhibitor of $\mathrm{K}^{+}$-ATP-channels 5-hydroxydecanoate significantly decreased the ability of NaHS $\left(10^{-4} \mathrm{M}\right)$ to prevent mitochondrial swelling under ischemia/ reperfusion of myocardium [104].

Inhalation of $\mathrm{H}_{2} \mathrm{~S}$ aimed at cytoprotection is used in some studies, and concentrations of 50$400 \mathrm{ppm}$ which cause mitochondrial dysfunction, are sublethal. $\mathrm{H}_{2} \mathrm{~S}$ in concentration up to $10 \mathrm{ppm}$ does not create disorder in activity of mitochondrial enzymes [26]. The perfusion of lungs by gas mixture with $\mathrm{H}_{2} \mathrm{~S}$ in concentration of 50 and $100 \mu \mathrm{mol} / 1$ decreased oxidative disorders at pulmonal ischemia/ reperfusion in mice [80].

Inorganic $\mathrm{H}_{2} \mathrm{~S}$ donors quickly increase its content in blood plasma and tissues, but they are also quickly eliminated from the organism in a form of sulfides, thiosulfates, sulfites, sulfates. More slow increase of $\mathrm{H}_{2} \mathrm{~S}$ content in tissues provide $\mathrm{H}_{2} \mathrm{~S}$ synthesing enzymes substrates such as L-cysteine, $\mathrm{D}$-cysteine; L-cysteine derivatives such as $\mathrm{N}$-acetylcysteine, S-propalgyl-L-cysteine, S-propyl-Lcysteine, S-allyl-L-cysteine; polysulfides (diallyl disulfide, diallyl trisulfide) and artificial organic donor of $\mathrm{H}_{2} \mathrm{~S}$ - Lawesson's reagent $[68,85,105]$. Sodium thiosulfate may also play the role of inorganic substrate for endogenous $\mathrm{H}_{2} \mathrm{~S}$ production. For example, the injection of L-cysteine (15 and $100 \mathrm{mg} / \mathrm{kg}$ ) stimulated epithelialization of gastric ulcer in rats [86]. Dcysteine protects neurons of cerebellum from oxidative stress and decreases damage of kidneys under condition of ischeamia-reperfusion more effectively than L-cysteine [12]. S-propalgyl-L-cysteine, S-propyl-L-cysteine, S-allyl-L-cysteine showed cardioprotective action under acute myocardial infarction in rats, increased $\mathrm{H}_{2} \mathrm{~S}$ content and increased activity of superoxide dismutase (Mn-SOD) in cardiomyocytes
[105]. Administration of sodium thiosulfate (3 mg/ $\mathrm{ml}$ with drinking water for 6 weeks) normalized cardial $\mathrm{H}_{2} \mathrm{~S}$ production in rats with chronic heart failure [87].

To reach a decrease of $\mathrm{H}_{2} \mathrm{~S}$ endogenous production the $\mathrm{H}_{2} \mathrm{~S}$-synthesizing enzymes have been used: inhibitors of CSE - DL-propargylglycine, $\beta$-cyanoalanine or inhibitors of CBS - hydroxylamine, aminooxyacetate. As a rule, inhibitors of $\mathrm{H}_{2} \mathrm{~S}$-synthesizing enzymes demonstrate vasoconstriction, cytotoxic, pro-oxidant and pro-inflammatory action $[7,15,17,34,68,80,81]$. For example, the injection of DL-propargylglycine caused a decrease in activity of mitochondrial electron transport chain Complex I, decrease of glutathione content and development of oxidative stress in the brain of mice [36]; increased ischaemia-reperfusion damages and increased size of myocardial infarction, worsened functional condition of kidneys and increased content of creatinine in blood serum of rats [80]. Seven-day injection of propargylglycine $(50 \mathrm{mg} / \mathrm{kg})$ caused activation of blood coagulation and increased ADP-induced aggregation of thrombocytes in rats [88]. With excessive $\mathrm{H}_{2} \mathrm{~S}$ in tissues, the inhibitors of $\mathrm{H}_{2} \mathrm{~S}$-synthesizing enzymes may show cytoprotector action. Propargylglycine injection $(8-10 \mathrm{mg} / \mathrm{kg})$ decreased features of acute turbular necrosis, prevented the increase of serum creatinine and decreased $\mathrm{H}_{2} \mathrm{~S}$ creation in rats' kidneys under gentamicyne administration [89].

Taking into consideration $\mathrm{H}_{2} \mathrm{~S}$ physiological effects, the attempts have been made to modify effectiveness and toxicity of medicines with the help of its donors. Thus there appeared $\mathrm{H}_{2} \mathrm{~S}$-releasing drugs, and $\mathrm{H}_{2} \mathrm{~S}$-derivatives of nonsteroidal anti-inflammatory drugs (NSAIDs) became their first example. It has been proved that one of the mechanisms of gastroduodenal toxicity of NSAIDs is a decrease of $\mathrm{H}_{2} \mathrm{~S}$ endogenous production [90]. $\mathrm{H}_{2} \mathrm{~S}$-derivatives, S-diclofenac, S-naproxen, S-aspirin possess a higher anti-inflammatory action and lower gastrotoxicity than their prototypes [86, 91]. $\left(\mathrm{H}_{2} \mathrm{~S}+\mathrm{NO}\right)$-derivatives of aspirin and $\mathrm{H}_{2} \mathrm{~S}$-derivatives of other pharmacological means - L-DOPA $\left(\mathrm{ACS}_{83-86}\right)$, sildenafil (ACS6) and mesalamin (ATB-429) were made later [68].

Pharmaceutical means may influence $\mathrm{H}_{2} \mathrm{~S}$ content in animals' organs in different ways. For example, paracetamol decreased $\mathrm{H}_{2} \mathrm{~S}$ concentration in brain, but increased its concentration in the heart, liver and kidneys of mice [92]. Amplodipin caused a decrease of $\mathrm{H}_{2} \mathrm{~S}$ level in the brain and liver of mice 
in a dose of 3 and $10 \mathrm{mg} / \mathrm{kg}$, but caused its increase in the heart and kidneys in a dose of $3 \mathrm{mg} / \mathrm{kg}$ and its decrease in a dose of $10 \mathrm{mg} / \mathrm{kg}$ [56]. It has been demonstrated as well that aspirin decreased $\mathrm{H}_{2} \mathrm{~S}$ level in the brain and increased its level in the liver of mice [93]. Carvedilol (in a dose of $10 \mathrm{mg} / \mathrm{kg}$ ) caused an increase of $\mathrm{H}_{2} \mathrm{~S}$ content in the heart, kidneys and brain of mice [94]. The same effect was caused by digoxin [54], atorvastatin [92], ramipril [95], and metformin [96].

Medicines' influence on $\mathrm{H}_{2} \mathrm{~S}$ content in tissues, and their interaction with $\mathrm{H}_{2} \mathrm{~S}$ donors and inhibitors of $\mathrm{H}_{2} \mathrm{~S}$-synthesising enzymes are not known well. It is proved that atorvastatin increases $\mathrm{H}_{2} \mathrm{~S}$ content in perivascular adipose tissue at the expence of inhibition of its mitochondria utilization, but does not influence the CSE activity. Atovastatin disrupts endogenous production of cofactor of sulfide quinone oxidoreductase - ubiquinone that significantly decreases its content in the blood plasma and tissues of animals [97]. Other drugs may be non-specific activators or inhibitors of $\mathrm{H}_{2} \mathrm{~S}$-synthesizing enzymes. We have shown that a single injection of cysplatine $(7 \mathrm{mg} / \mathrm{kg})$ causes a significant decrease of CSE, CBS and CAT activity in the rat kidneys, that is associated with a decrease of $\mathrm{H}_{2} \mathrm{~S}$ level and increase of homocysteine level in the blood plasma. The injection of DL-propargylglycine $(50 \mathrm{mg} / \mathrm{kg})$ potentiated nephrotoxic effect of cysplatine, while NaHS injection ( $3 \mathrm{mg} / \mathrm{kg}$ ), on the contrary, decreased cysplatineinduced nephropathia, increased glutathione content and glutamate-cysteine ligase in the rat kidneys [98].

It is not improbable that inorganic and organic donors of $\mathrm{H}_{2} \mathrm{~S}$ may significantly impact biotransformation of medicines. NaHS peroral administration $(5 \mathrm{mg} / \mathrm{kg})$ caused a decrease of CYP2C9 activity, increase of CYP3A4 activity and had no influence on CYP2B6, CYP2D6 and CYP2C19 activity in rats [99].

Search for safe and effective $\mathrm{H}_{2} \mathrm{~S}$ modulators is continued. In our opinion, the drugs containing activators and cofactors of $\mathrm{H}_{2} \mathrm{~S}$-synthesizing enzymes, vitamin-microelements complexes, are perspective. We have showed in some studies that under longterm hyperhomocystenemia in rats $\mathrm{H}_{2} \mathrm{~S}$ content in the blood plasma and $\mathrm{H}_{2} \mathrm{~S}$-synthesizing enzymes activity (CSE, CBS, CAT, TST) in the liver, kidneys, aorta is decreased. Administration of vitaminmicroelement complex (VMC), which contains vitamins $\mathrm{B}_{6}, \mathrm{~B}_{9}, \mathrm{~B}_{12}$ and coordinating compositions of zinc $\left(\mathrm{Zn}^{2+}\right)$ and chrome $\left(\mathrm{Cr}^{3+}\right)$ with $\mathrm{N}-2,3$-dimethyl- phenylanthranilic acid and ammonium vanadate $\left(\mathrm{V}^{5+}\right)$, effectively increased endogenous $\mathrm{H}_{2} \mathrm{~S}$ production from cysteine, homocysteine, thiosulfate in rats' organs. The $\mathrm{H}_{2} \mathrm{~S}$ production was also increased under the condition of combination of cysteine, homocysteine, thiosulfate in rats' organs with hyperhomocysteinemia and also under its combination with nitric oxide synthase inhibitor L-NAME [57]. A complex of essential microelements (iron, copper, zinc, cobalt, manganese, chrome) and oxygencontaining salts of ultramicroelements (vanadium, molybdenum and selenium) - esmin (Esmin, PC "Kyiv Vitamin Factory") in a dose of $35 \mathrm{mg} / \mathrm{kg}$ decreased age-associated reduction of $\mathrm{H}_{2} \mathrm{~S}$ production in the myocardium, aorta and kidneys of rats [100]. The above-mentioned microelements are necessary for the broad range of biochemical processes; in particular, they are cofactors or activators of antioxidant enzymes and enzymes of sulfur-containing amino acids metabolism, involved in cardiovascular homeostasis and tissue respiration.

Thus a great body of scientific information about $\mathrm{H}_{2} \mathrm{~S}$ role in biology and medicine (Scheme) was accumulated within the last ten years. $\mathrm{H}_{2} \mathrm{~S}$ metabolism modulation has assumed great significance in determining mechanisms of formation of different pathological conditions, in development of new approaches to their preventive maintenance and correction, in increasing effectiveness and safety of pharmacotherapy and in development of many other directions, which amount increases. In our opinion, there is a necessity for systematization of $\mathrm{H}_{2} \mathrm{~S}$ metabolism modulators and creation of their working classification. We propose to divide modulators of $\mathrm{H}_{2} \mathrm{~S}$ metabolism, which are used in biology and medicine, into groups and subgroups in respect of their impact on endogenous $\mathrm{H}_{2} \mathrm{~S}$ in tissues and mechanism of their action (Table 8):

1) means that increase $\mathrm{H}_{2} \mathrm{~S}$ content in tissues (with regard to action mechanism, they are divided into $\mathrm{H}_{2} \mathrm{~S}$ donors; $\mathrm{H}_{2} \mathrm{~S}$-synthesising substrates of enzymes and their derivatives; $\mathrm{H}_{2} \mathrm{~S}$-releasing drugs; remedies containing cofactors and activators of $\mathrm{H}_{2} \mathrm{~S}$ synthesizing enzymes; drugs inhibiting $\mathrm{H}_{2} \mathrm{~S}$ utilization);

2) means that decrease $\mathrm{H}_{2} \mathrm{~S}$ content in tissues (with regard to action mechanism, they are divided into specific and non-specific inhibitors of $\mathrm{H}_{2} \mathrm{~S}$-synthesizing enzymes);

3) means with indeterminate mechanism of impact on $\mathrm{H}_{2} \mathrm{~S}$ metabolism. This group contains phar- 


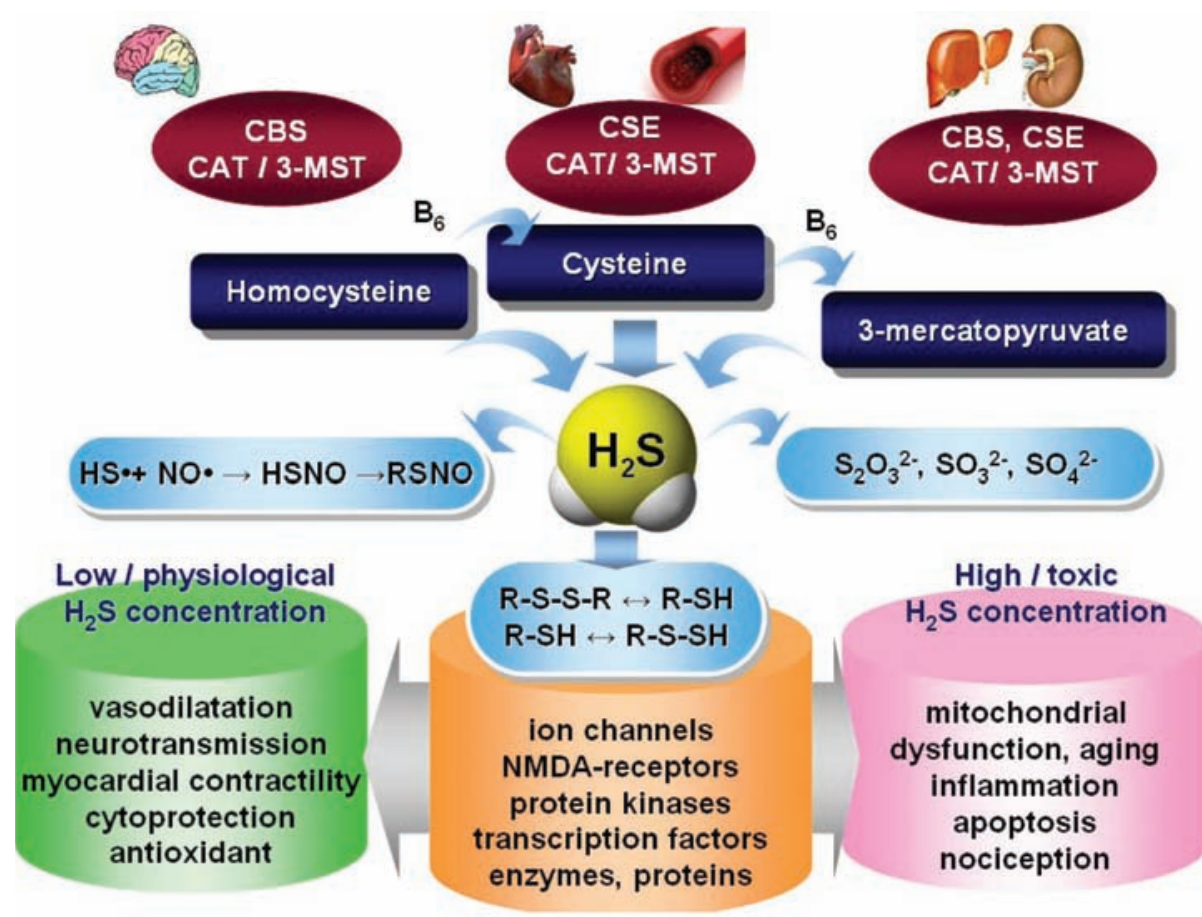

Scheme. Main directions of metabolism and biological effects of $\mathrm{H}_{2} \mathrm{~S}$

Ta ble 8. Classification of $\mathrm{H}_{2} \mathrm{~S}$ metabolism modulators, which are used in biology and medicine

\begin{tabular}{|c|c|c|}
\hline & Groups & Representatives \\
\hline \multicolumn{3}{|c|}{ 1. Agents that increase $\mathrm{H}_{2} \mathrm{~S}$ content in tissues } \\
\hline 1.1 & $\mathrm{H}_{2} \mathrm{~S}$ donors & $\begin{array}{l}\text { Inorganic }-\mathrm{NaHS} \mathrm{Na}_{2} \mathrm{~S} ; \text { organic }- \\
\text { Lawesson's reagent }\end{array}$ \\
\hline 1.2 & $\begin{array}{l}\text { Substrates of } \mathrm{H}_{2} \mathrm{~S} \text {-synthesizing } \\
\text { enzymes and theirs derivatives }\end{array}$ & $\begin{array}{l}\text { L-cysteine, D-cysteine, N-acetylcysteine, } \\
\text { S-allyl-L-cysteine, S-propargyl-L-cysteine, } \\
\text { S-propyl-L-cysteine, sodium thiosulfate }\end{array}$ \\
\hline 1.3 & $\begin{array}{l}\text { Agents with } \mathrm{H}_{2} \mathrm{~S} \text { releasing effect } \\
\left(\mathrm{H}_{2} \mathrm{~S} \text {-releasing drugs) }\right.\end{array}$ & $\begin{array}{l}\mathrm{H}_{2} \mathrm{~S} \text {-derivatives of non-steroidal anti-inflammatory } \\
\text { drugs (S-aspirin, S-diclofenac, S-naproxen), } \\
\text { L-DOPA (ACS83-86), sildenafil (ACS6) }\end{array}$ \\
\hline 1.4 & $\begin{array}{l}\text { Agents that contain cofactors and } \\
\text { activators of } \mathrm{H}_{2} \mathrm{~S} \text {-synthesizing enzymes }\end{array}$ & $\begin{array}{l}\text { Vitamin-microelement and polymicroelement } \\
\text { complexes (VMC and esmin) }\end{array}$ \\
\hline 1.5 & Agents that inhibit $\mathrm{H}_{2} \mathrm{~S}$ utilization & atorvastatin \\
\hline \multicolumn{3}{|c|}{ 2. Agents that decrease $\mathrm{H}_{2} \mathrm{~S}$ in tissues } \\
\hline 2.1 & $\begin{array}{l}\text { Specific inhibitors of } \mathrm{H}_{2} \mathrm{~S}- \\
\text { synthesizing enzymes }\end{array}$ & $\begin{array}{l}\text { DL-propargylglycine, } \beta \text {-cyanoalanine, } \\
\beta \text {-aminooxyacetate, hydroxylamine }\end{array}$ \\
\hline 2.2 & $\begin{array}{l}\text { Nonspecific inhibitors of } \mathrm{H}_{2} \mathrm{~S}- \\
\text { synthesizing enzymes }\end{array}$ & $\begin{array}{l}\text { non steroidal anti-inflammatory drugs (diclofenac, } \\
\text { ketoprofen, indomethacin, aspirin), cisplatin }\end{array}$ \\
\hline \multicolumn{3}{|c|}{ 3. Agents with indefinite mechanism of action on $\mathrm{H}_{2} \mathrm{~S}$ metabolism } \\
\hline 3.1 & Increase $\mathrm{H}_{2} \mathrm{~S}$ in tissues & $\begin{array}{l}\text { carvedilol, digoxin, ramipril, paracetamol } \\
\text { (in liver, kidneys), metformin, amlodipin }\end{array}$ \\
\hline 3.2 & Decrease $\mathrm{H}_{2} \mathrm{~S}$ in tissues & paracetamol (in brain), amlodipin \\
\hline
\end{tabular}


macology means, influence of which on $\mathrm{H}_{2} \mathrm{~S}$ metabolism necessitates further study.

It is obvious that the proposed classification of $\mathrm{H}_{2} \mathrm{~S}$ will change with the extension of the range of its representatives, with determination and clarification of their action mechanisms. There are many unsolved problems concerning molecular targets, ways of $\mathrm{H}_{2} \mathrm{~S}$-signaling realizations, regulation mechanisms of $\mathrm{H}_{2} \mathrm{~S}$ synthesis and degradation under the effect of different endogenous and exogenous factors. Solution of these problems opens new prospects in development of medical biochemistry and pharmacology.

\section{ГІДРОГЕНСУЛЬФІД: МЕТАБОЛІЗМ, БІОЛОГІЧНЕ ТА МЕДИЧНЕ ЗНАЧЕННЯ}

\section{Н. В. Заічко, А. В. Мельник, \\ М. М. Йолтухівський, О. С. Ольховський, I. В. Паламарчук}

Вінницький національний медичний університет ім. М. І. Пирогова, Україна; e-mail: nzaichko@mail.ru

Гідрогенсульфід $\left(\mathrm{H}_{2} \mathrm{~S}\right)$ є сигнальною молекулою, яка активно синтезується в тканинах i бере участь у регуляції судинного тонусу, нейромодуляції, цитопротекції, в запаленні, апоптозі. В останні роки накопичились нові дані про метаболізм та функції $\mathrm{H}_{2} \mathrm{~S}$ в організмі тварин та людини в умовах дії різних ендогенних та екзогенних чинників, у тому числі і лікарських засобів. У представленому огляді узагальнено інформацію про основні та альтернативні шляхи метаболізму $\mathrm{H}_{2} \mathrm{~S}$ та їх регуляцію, особливості його транспортування, сигналінгу, біологічну роль, участь в розвитку патологічних станів. Наведено дані щодо вмісту $\mathrm{H}_{2} \mathrm{~S}$ та активності $\mathrm{H}_{2} \mathrm{~S}$-синтезуючих ензимів у різних органах, щодо впливу $\mathrm{H}_{2} \mathrm{~S}$ на процеси зсідання крові та агрегації тромбоцитів з урахуванням результатів власних досліджень. Запропоновано робочу класифікацію модуляторів обміну $\mathrm{H}_{2} \mathrm{~S}$, які використовуються в біології та медицині: 1) засоби, що підвищують вміст $\mathrm{H}_{2} \mathrm{~S}$ у тканинах (неорганічні та органічні донори $\mathrm{H}_{2} \mathrm{~S}$; субстрати $\mathrm{H}_{2} \mathrm{~S}$-синтезуючих ензимів та їх деривати; засоби 3 ефектом вивільнення $\mathrm{H}_{2} \mathrm{~S}$; засоби, що містять кофактори та активатори $\mathrm{H}_{2} \mathrm{~S}-$ синтезуючих ензимів; засоби, які інгібують утилізацію $\left.\mathrm{H}_{2} \mathrm{~S}\right)$; 2) засоби, що знижують вміст $\mathrm{H}_{2} \mathrm{~S}$ у тканинах (специфічні та неспецифічні інгібітори $\mathrm{H}_{2} \mathrm{~S}$-синтезуючих ензимів); 3) засоби 3 невизначеним механізмом впливу на обмін $\mathrm{H}_{2} \mathrm{~S}$ (окремі фармакологічні засоби). Показано, що перспективними засобами для корекції вмісту $\mathrm{H}_{2} \mathrm{~S}$ у тканинах є вітамінно-мікроелементні та мікроелементні комплекси, які містять кофактори та активатори $\mathrm{H}_{2} \mathrm{~S}$-синтезуючих ензимів.

К л ю чо в і с ло в а: гідрогенсульфід, $\mathrm{H}_{2} \mathrm{~S}$ сигналінг, ензими, регуляція, модулятори обміну $\mathrm{H}_{2} \mathrm{~S}$, комплекси вітамінів та мікроелементів.

\section{ГИДРОГЕНСУЛЬФИД: МЕТАБОЛИЗМ, БИОЛОГИЧЕСКОЕ И МЕДИЦИНСКОЕ ЗНАЧЕНИЕ}

\section{Н. В. Заичко, А. В. Мельник, \\ Н. М. Йолтуховский, А. С. Ольховский, И. В. Паламарчук}

Винницкий национальный медицинский университет им. Н. И. Пирогова, Украина; e-mail:nzaichko@mail.ru

Гидрогенсульфид $\left(\mathrm{H}_{2} \mathrm{~S}\right)$ является сигнальной молекулой, которая активно синтезируется в тканях и участвует в регуляции сосудистого тонуса, нейромодуляции, цитопротекции, воспалении, апоптозе. В последние годы накопились новые данные о метаболизме и функции $\mathrm{H}_{2} \mathrm{~S}$ в организме животных и человека под влиянием различных эндогенных и экзогенных факторов, в том числе и лекарственных средств. В представленном обзоре обобщена информация об основных и альтернативных путях метаболизма $\mathrm{H}_{2} \mathrm{~S}$ и их регуляции, особенности его транспорта, сигналинга, биологической роли, участие в развитии патологических состояний. Приведены данные о содержании $\mathrm{H}_{2} \mathrm{~S}$ и активности $\mathrm{H}_{2} \mathrm{~S}$ синтезирующих энзимов в различных органах, о влиянии $\mathrm{H}_{2} \mathrm{~S}$ на процессы свертывания крови и агрегации тромбоцитов с учетом результатов собственных исследований. Предложена рабочая классификация модуляторов обмена $\mathrm{H}_{2} \mathrm{~S}$, которые используются в биологии и медицине: 1) средства, повышающие содержание $\mathrm{H}_{2} \mathrm{~S}$ в тканях (неорганические и органические доноры $\mathrm{H}_{2} \mathrm{~S}$; субстраты $\mathrm{H}_{2} \mathrm{~S}$-синтезирующих энзимов и их дериваты, средства с эффектом высвобождения $\mathrm{H}_{2} \mathrm{~S}$; средства, содержащие кофакторы и активаторы $\mathrm{H}_{2} \mathrm{~S}$-синтезирующих энзимов; сред- 
ства, ингибирующие утилизацию $\left.\mathrm{H}_{2} \mathrm{~S}\right), 2$ ) средства, снижающие содержание $\mathrm{H}_{2} \mathrm{~S}$ в тканях (специфические и неспецифические ингибиторы $\mathrm{H}_{2} \mathrm{~S}$-синтезирующих энзимов), 3) средства с неопределенным механизмом влияния на обмен $\mathrm{H}_{2} \mathrm{~S}$ (отдельные фармакологические средства). Показано, что перспективными средствами для коррекции содержания $\mathrm{H}_{2} \mathrm{~S}$ в тканях является витаминно-микроэлементные и микроэлементные комплексы, содержащие кофакторы и активаторы $\mathrm{H}_{2} \mathrm{~S}$-синтезирующих энзимов.

Кл юче вы е с слов а: гидрогенсульфид, $\mathrm{H}_{2} \mathrm{~S}-$ сигналинг, энзимы, регуляция, модуляторы обмена $\mathrm{H}_{2} \mathrm{~S}$, комплексы витаминов и микроэлементов.

\section{References}

1. Abe K., Kimura H. The possible role of hydrogen sulfide as an endogenous neuromodulator. J. Neurosci. 1996;16(3):1066-1071.

2. Wang R. Two's company, three's a crowd: $\mathrm{can}_{2} \mathrm{~S}$ be the third endogenous gaseous transmitter? FASEB J. 2002;16:1792-1798.

3. Lowicka E., Beltowski J. Hydrogen sulfide $\left(\mathrm{H}_{2} \mathrm{~S}\right)-$ the third gas of interest for pharmacologists. Pharmacol. Rep. 2007;59:4-24.

4. Miasoedova O. A., Korzhov V. I. Role of hydrogen sulfide in the realization of organism's physiological functions. J. NAMS Ukraine. 2011;17(3):191-200. (In Russian).

5. Gadalla M. M., Snyder S. H. Hydrogen sulfide as a gasotransmitter. J. Neurochem. 2010;113:14-26.

6. Kimura H. Hydrogen sulfide: its production and functions. Exp. Physiol. 2011;96(9):833-835.

7. Wang J. F., Li Y., Song J. N., Pang H. G. Role of hydrogen sulfide in secondary neuronal injury. Neurochem. Int. 2014;64:37-47.

8. Cuevasanta E., Denicola A., Alvarez B., Moller M. N. Solubility and Permeation of Hydrogen Sulfide in Lipid Membranes. PLoS ONE. 2012;7(4): e34562. doi:10.1371/journal. pone. 0034562.

9. Jennings M. L. Transport of hydrogen sulfide and hydrosulfide anion across the human red blood cell membrane. Rapid $\mathrm{H}_{2} \mathrm{~S}$ diffusion and AE1mediated Cl-/HS- exchange. Am. J. Physiol. Cell Physiol. 2013;305(9):941-950.

10. Mathai J. C., Missner A., Kugler P., Saparov S. M., Zeidel M. L., Lee J. K., and Pohl P. No facilitator required for membrane transport of hydrogen sulfide. Proc. Natl. Acad. Sci. USA. 2009;106(39):16633-16638.

11. Shibuya N., Mikami Y., Kimura Y., Nagahara N., Kimura H. Vascular endothelium expresses 3-mercaptopyruvate sulfurtransferase and produces hydrogen sulfide. J. Biochem. 2009;146(5):623-626.

12. Shibuya N., Kimura H. Production of hydrogen sulfide from d-cysteine and its therapeutic potential. Front Endocrinol. (Lausanne). 2013;4:87. doi: 10.3389/fendo.2013.00087.

13. Singh S., Padovani D., Leslie T. Chiku R. A., Banerjee R. Relative contributions of cystathionine beta-synthase and gammacystathionase to $\mathrm{H}_{2} \mathrm{~S}$ biogenesis via alternative trans-sulfuration reactions. J. Biol. Chem. 2009;284(33):22457-22466.

14. Chiku T., Padovani D., Zhu W., Singh S., Vitvitsky V., Banerjee R. $\mathrm{H}_{2} \mathrm{~S}$ biogenesis by human cystathionine gamma-lyase leads to the novel sulfur metabolites lanthionine and homolanthionine and is responsive to the grade of hyperhomocysteinemia. J. Biol. Chem. 2009;284(17):11601-11612.

15. Kimura H. Physiological role of hydrogen sulfide and polysulfide in the central nervous system. Neurochem. Int. 2013;63(5):492-497.

16. Yadav P. K., Yamada K., Chiku T., Koutmos M., Banerjee R. Structure and kinetic analysis of $\mathrm{H}_{2} \mathrm{~S}$ production by human mercaptopyruvate sulfurtransferase. J. Biol. Chem. 2013;288(27):20002-20013.

17. Kimura H., Shibuya N., Kimura Y. Hydrogen sulfide is a signaling molecule and a cytoprotectant. Antioxid. Redox Signal. 2012;17(1):45-57.

18. Tanizawa K. Production of $\mathrm{H}_{2} \mathrm{~S}$ by 3-mercaptopyruvate sulphurtransferase. J. Biochem. 2011;149(4):357-359.

19. Zaichko N. V. Homocysteine, cysteine, and hydrogen sulfide blood level in patients with thrombophylia: relationship with methylenetetrahydrofolate reductase C677T polymorphism. Exp. Clin. Physiol. Biochem. J. 2010;(4):35-41. (In Ukrainian).

20. Yang F., Tan H.-V., Wang H. Hyperhomocysteinemia and atherosclerosis.Acta Physiol. Sin. 2005;57(2):103-114.

21. Nakanishi T., Hasuike Y., Otaki Y., Hama Y., Nanami M., Miyagawa K, Moriguchi R, Nishikage H., Izumi M., Takamitsu Y. Free 
cysteine is increased in plasma from hemodialysis patients. Kidney Int. 2003;63:1137-1140.

22. Zaichko N. V., Pentiuk N. A., Melnik A. V., Shtatko E. I., Andrushko I. I. Production of hydrogen sulfide in organs of rats. Med. Chem. 2009;11(4):7-13. (In Ukrainian).

23. Stein A., Bailey Sh. M. Redox biology of hydrogen sulfide: Implications for physiology, pathophysiology, and pharmacology. Redox Biology. 2013;(1):32-39.

24. Jackson M. R., Melideo S. L., Jorns M. S. Human sulfide:quinone oxidoreductase catalyzes the first step in hydrogen sulfide metabolism and produces a sulfane sulfur metabolite. Biochemistry. 2012;51(34):6804-6815.

25. Zhao H., Chan S-J., Ng Y-K., Wong PT-H. Brain 3-mercaptopyruvate sulfurtransferase (3MST): cellular localization and downregulation after acute stroke. PLOS ONE. 2013;8(6):e67322. doi:10.1371/journal.pone.0067322.

26. Guo W., Kan J. T., Cheng Z. Y., Chen J. F., Shen Y. Q., Xu J., Wu D., Zhu Y. Z. Hydrogen sulfide as an endogenous modulator in mitochondria and mitochondria dysfunction. Oxid. Med. Cell Longev. 2012;2012:878052 doi: 10.1155/2012/878052.

27. Filipovic M. R., Miljkovic J. Lj., Nauser T., Royzen M., Klos K., Shubina T., Koppenol W. H., Lippard S. J., Ivanović-Burmazović I. Chemical characterization of the smallest S-nitrosothiol, HSNO; cellular cross-talk of $\mathrm{H}_{2} \mathrm{~S}$ and S-nitrosothiols. J. Am. Chem. Soc. 2012;134(29):12016-12027.

28. Kolluru G. K., Shen X., Kevil C. G. A tale of two gases: $\mathrm{NO}$ and $\mathrm{H}_{2} \mathrm{~S}$, foes or friends for life? Redox Biol. 2013;23(1):313-318.

29. Stipanuk M.H., Beck P. W. Characterization of the enzymic capacity for cysteine desulphhydration in liver and kidney of the rat. Biochem. J. 1982;206(2):267-277.

30. Bao L., Vlcek C., Paces V., Kraus J. P. Identification and tissue distribution of human cystathionine beta-synthase mRNA isoforms. Arch. Biochem. Biophys. 1998;350(1):95-103.

31. Levonen A. L., Lapatto R., Saksela M., Raivio K. O. Human cystathionine gammalyase: developmental and in vitro expression of two isoforms. Biochem. J. 2000;347(1.):291-295.

32. Yamamoto J., Sato W., Kosugi T., Yamamoto T., Kimura T., Taniguchi S., Kojima H., Maruyama S., Imai E., Matsuo S., Yuzawa Y.,
Niki I. Distribution of hydrogen sulfide $\left(\mathrm{H}_{2} \mathrm{~S}\right)$ producing enzymes and the roles of the $\mathrm{H}_{2} \mathrm{~S}$ donor sodium hydrosulfide in diabetic nephropathy. Clin. Exp. Nephrol. 2013;17(1):32-40.

33. Fan Q. L., Yang G., Liu X. D., Ma J. F., Feng J. M., Jiang Y., Wang L. N. Effect of losartan on the glomerular protein expression profile of type 2 diabetic KKAy mice. J. Nephrol. 2013;26(3):517526.

34. Guo W., Cheng Z. Y., Zhu Y. Z. Hydrogen sulfide and translational medicine. Acta Pharmacol. Sin. 2013;34(10):1284-1291.

35. Zhang M., Shan H., Wang T., Liu W., Wang Y., Wang L., Zhang L., Chang P., Dong W., Chen X., Tao L. Dynamic change of hydrogen sulfide after traumatic brain injury and its effect in mice. Neurochem. Res. 2013;38(4):714-725.

36. Diwakar L., Ravindranath V. Inhibition of cystathionine-gamma-lyase leads to loss of glutathione and aggravation of mitochondrial dysfunction mediated by excitatory amino acid in the CNS. Neurochem. Int. 2007;50(2):418-426.

37. Wang Q., Liu H.R., Mu Q., Rose P., Zhu Y.Z. S-propargyl-cysteine protects both adult rat hearts and neonatal cardiomyocytes from ischemia/hypoxia injury: the contribution of the hydrogen sulfide-mediated pathway. J. Cardiovasc. Pharmacol. 2009;54(2):139-146.

38. Nagahara N., Ito T., Kitamura H., Nishino T. Tissue and subcellular distribution of mercaptopyruvate sulfurtransferase in the rat: confocal laser fluorescence and immunoelectron microscopic studies combined with biochemical analysis. Histochem. Cell Biol. 1998;110(3):243250.

39. Chen Y., Zhao J., Du J., Xu G., Tang C., Geng B. Hydrogen sulfide regulates cardiac sarcoplasmic reticulum $\mathrm{Ca}\left({ }^{2+}\right)$ uptake via $\mathrm{K}(\mathrm{ATP})$ channel and PI3K/Akt pathway. Life Sci. 2012;91(7-8):271-278.

40. Du J. T., Li W., Yang J. Y., Tang C. S., Li Q., Jin H. F. Hydrogen sulfide is endogenously generated in rat skeletal muscle and exerts a protective effect against oxidative stress. Chin. Med. J. (Engl). 2013;126(5):930-936.

41. You X. J., Xu C., Lu J. Q., Zhu X. Y., Gao L., Cui X. R., Li Y., Gu H., Ni X. Expression of cystathionine $\beta$-synthase and cystathionine $\gamma$-lyase in human pregnant myometrium and their roles in the control of uterine contractility. PLoS One. 2011;6(8):e23788. doi:10.1371/journal. pone. 0023788 . 
42. Patel P., Vatish M., Heptinstall J., Wang R., Carson R. J. The endogenous production of hydrogen sulphide in intrauterine tissues. Reprod. Biol. Endocrinol. 2009;7:10 doi:10.1186 /1477-7827-7-10.

43. Martin G. R., McKnight G. W., Dicay M. S., Coffin C. S., Ferraz J. G., Wallace J. L. Hydrogen sulphide synthesis in the rat and mouse gastrointestinal tract. Dig. Liver Dis. 2010;42(2):103-109.

44. Taniguchi S., Niki I. Significance of hydrogen sulfide production in the pancreatic $\beta$-cell. $J$. Pharmacol. Sci. 2011;116(1):1-5.

45. Okamoto M., Yamaoka M., Kimura T. Hydrogen sulfide and its effect on pancreatic beta-cells. Nihon Rinsho. 2013;71(1):175-80.

46. Feng X., Chen Y., Zhao J., Tang C., Jiang Z., Geng B. Hydrogen sulfide from adipose tissue is a novel insulin resistance regulator. Biochem. Biophys. Res. Commun. 2009;380(1):153-159.

47. Chen Y. H., Wu R., Geng B., Qi Y. F., Wang P. P., Yao W. Z., Tang C. S. Endogenous hydrogen sulfide reduces airway inflammation and remodeling in a rat model of asthma. Cytokine. 2009;45(2):117-123.

48. Fang L. P., Lin Q., Tang C. S., Liu X. M. Hydrogen sulfide attenuates epithelial-mesenchymal transition of human alveolar epithelial cells. Pharmacol. Res. 2010;61(4):298-305.

49. Akagi R. Purification and characterization of cysteine aminotransferase from rat liver cytosol. Acta Med. Okayama. 1982;36(3):187-197.

50. Taoka S., Banerjee R. Characterization of NO binding to human cystathionine beta-synthase: possible implications of the effects of $\mathrm{CO}$ and NO binding to the human enzyme. J. Inorg. Biochem. 2001;87(4):245-251.

51. Agrawal N., Banerjee R. Human polycomb 2 protein is a SUMO E3 ligase and alleviates substrate-induced inhibition of cystathionine beta-synthase sumoylation. PLoS One. 2008;3(12):e4032. doi: 10.1371/journal. pone.0004032.

52. Yang G., Wu L., Jiang B., Yang W., Qi J., Cao K., Meng Q., Mustafa A. K., Mu W., Zhang S., Snyder S. H., Wang R. $\mathrm{H}_{2} \mathrm{~S}$ as a physiologic vasorelaxant: hypertension in mice with deletion of cystathionine gamma-lyase. Science. 2008;5901(322):587-590.

53. Zaichko N. V., Pentiuk N. O., Pentiuk L. O., Melnik A. V., Shtatko E. I., Andrushko I. I..
Determination of hydrogen sulfide in blood serum. J. Res. 2009;(1):29-32. (In Ukrainian).

54. Wiliński B., Wiliński J., Somogyi E., Piotrowska J., Góralska M., Macura B. Carvedilol induces endogenous hydrogen sulfide tissue concentration changes in various mouse organs. Folia Biol. (Krakow). 2011;59(3-4):151-155.

55. Furne J., Saeed A., Levitt M. D. Whole tissue hydrogen sulfide concentrations are orders of magnitude lower than presently accepted values. Am. J. Physiol. Regul. Integr. Comp. Physiol. 2008;295(5):1479-1485.

56. Wiliński B., Wiliński J., Somogyi E., Piotrowska J., Góralska M. Amlodipine affects endogenous hydrogen sulfide tissue concentrations in different mouse organs. Folia Med. Cracov. 2011;51(1-4):29-35.

57. Melnik A. V. The activity of transsulfuration and methylation enzymes in rats kidney under prolonged administration of homocysteine thiolactone, its combination with L-NAME and correction of violations by the vitamin and microelement complex. Biomed. Biosocial. Anthropol. 2010;(14):58-62. (In Ukrainian).

58. Olhovskiy A. S., Zaichko N. V., Melnik A. V. Agerelated differences in production ofhydrogen sulfide in heart and aorta of rats. Urgent Probl. Mod. Med. 2011;11(4):133-137. (In Ukrainian).

59. Mustafa A. K., Gadalla M. M., Sen N., Kim S., Mu W., Gazi S. K., Barrow R. K., Yang G., Wang R., Snyder S. H. H S signals through protein S-sulfhydration. Sci. Signal. 2009;2(96):72. doi: 10.1126/scisignal.2000464.

60. Wang X. B., Jin H. F., Tang C. S., Du J. B. The biological effect of endogenous sulfur dioxide in the cardiovascular system. Eur. J. Pharmacol. 2011;670(1):1-6.

61. Du S. X., Jin H. F., Bu D. F., Zhao X., Geng B., Tang C. S., Du J. B. Endogenously generated sulfur dioxide and its vasorelaxant effect in rats. Acta Pharmacol. Sin. 2008;29(8):923-930.

62. Schreier S.M., Muellner M.K., Steinkellner H., Hermann M., Esterbauer H., Exner M., Gmeiner B.M., Kapiotis S., Laggner H. Hydrogen sulfide scavenges the cytotoxic lipid oxidation product 4-HNE. Neurotox. Res. 2010;17(3):249-256.

63. Tang G., Wu L., Wang R. Interaction of hydrogen sulfide with ion channels. Clin. Exp. Pharmacol. Physiol. 2010;37(7):753-763.

64. Kawabata A., Ishiki T., Nagasawa K., Yoshida S., Maeda Y., Takahashi T., Sekiguchi F., Wada T., 
Ichida S., Nishikawa H. Hydrogen sulfide as a novel nociceptive messenger. Pain. 2007;132(1-2):74-81.

65. Yang H. Y., Wu Z. Y., Wood M., Whiteman M., Bian J. S. Hydrogen Sulfide Attenuates Opioid Dependence by Suppression of Adenylate Cyclase/cAMP Pathway. Antioxid. Redox Signal. 2014;20(1):31-41.

66. Lu M., Liu Y. H., Ho C. Y., Tiong C. X., Bian J. S. Hydrogen sulfide regulates cAMP homeostasis and renin degranulation in As4.1 and rat reninrich kidney cells. Am. J. Physiol. Cell Physiol. 2012;302(1):59-66.

67. Módis K., Panopoulos P., Coletta C., Papapetropoulos A., Szabo C. Hydrogen sulfide-mediated stimulation of mitochondrial electron transport involves inhibition of the mitochondrial phosphodiesterase 2A, elevation of cAMP and activation of protein kinase A. Biochem. Pharmacol. 2013. 86(9):1311-1319.

68. Caliendo G., Cirino G., Santagada V., Wallace J. L. Synthesis and biological effects of hydrogen sulfide $\left(\mathrm{H}_{2} \mathrm{~S}\right)$ : development of $\mathrm{H}_{2} \mathrm{~S}$ releasing drugs as pharmaceuticals. J. Med. Chem. 2010;53(17):6275-6286.

69. Pan T. T., Neo K. L., Hu L. F., Yong Q. C., Bian J. S. $\mathrm{H}_{2} \mathrm{~S}$ preconditioning-induced PKC activation regulates intracellular calcium handling in rat cardiomyocytes. Am. J. Physiol. Cell Physiol. 2008;294(1):169-177.

70. Zhang Q., Fu H., Zhang H., Xu F., Zou Z., Liu M., Wang Q., Miao M., Shi X. Hydrogen sulfide preconditioning protects rat liver against ischemia/reperfusion injury by activating Akt-GSK-3 $\beta$ signaling and inhibiting mitochondrial permeability transition. PLoS One. 2013;8(9):e74422. doi:10.1371/journal. pone. 0074422 .

71. Xu W., Wu W., Chen J., Guo R., Lin J., Liao X., Feng J. Exogenous hydrogen sulfide protects H9c2 cardiac cells against high glucoseinduced injury by inhibiting the activities of the p38 MAPK and ERK1/2 pathways. Int. J. Mol. Med. 2013;32(4):917-925. doi: 10.3892/ ijmm.2013.1462.

72. Koike S., Ogasawara Y., Shibuya N., Kimura H., Ishii K. Polysulfide exerts a protective effect against cytotoxicity caused by t-buthylhydroperoxide through Nrf2 signaling in neuroblastoma cells. FEBS Lett. 2013;587(21):3548-3555.
73. Gao C., Xu D. Q., Gao C.J., Ding Q., Yao L.N., Li Z. C., Chai W. An exogenous hydrogen sulphide donor, NaHS, inhibits the nuclear factor $\kappa \mathrm{B}$ inhibitor kinase/nuclear factor $\kappa \mathrm{b}$ inhibitor/nuclear factor- $\kappa \mathrm{B}$ signaling pathway and exerts cardioprotective effects in a rat hemorrhagic shock model. Biol. Pharm. Bull. 2012;35(7):1029-1034.

74. Guo R., Wu K., Chen J., Mo L., Hua X., Zheng D., Chen P., Chen G., Xu W., Feng J. Exogenous Hydrogen Sulfide Protects against DoxorubicinInduced Inflammation and Cytotoxicity by Inhibiting p38MAPK/NFkB Pathway in H9c2 Cardiac Cells. Cell Physiol. Biochem. 2013;32(6):1668-1680.

75. Hua W., Chen Q., Gong F., Xie C., Zhou S., Gao L. Cardioprotection of $\mathrm{H}_{2} \mathrm{~S}$ by downregulating iNOS and upregulating HO-1 expression in mice with CVB3-induced myocarditis. Life Sci. 2013;93(24):949-954.

76. Majid A. S., Majid A. M., Yin Z. Q., Ji D. Slow regulated release of $\mathrm{H}_{2} \mathrm{~S}$ inhibits oxidative stress induced cell death by influencing certain key signaling molecules. Neurochem. Res. 2013;38(7):1375-1393.

77. Zhang Y., Tang Z. H., Ren Z., Qu S. L., Liu M. H., Liu L. S., Jiang Z. S. Hydrogen sulfide, the next potent preventive and therapeutic agent in aging and age-associated diseases. Mol. Cell Biol. 2013;33(6):1104-1113.

78. Huang X., Meng X. M., Liu D. H., Wu Y. S., Guo X., Lu H. L., Zhuang X.Y., Kim Y. C., Xu W. X. Different regulatory effects of hydrogen sulfide and nitric oxide on gastric motility in mice. Eur. J. Pharmacol. 2013;720(1-3):276-285.

79. Módis K., Coletta C., Erdélyi K., Papapetropoulos A., Szabo C. Intramitochondrial hydrogen sulfide production by 3-mercaptopyruvate sulfurtransferase maintains mitochondrial electron flow and supports cellular bioenergetics. FASEB J. 2013;27(2):601-611.

80. Nicholson C. K., Calvert J. W. Hydrogen sulfide and ischemia-reperfusion injury. Pharmacol. Res. 2010;62(4):289-297.

81. Mishra P. K., Tyagi N., Sen U., Givvimani S., Tyagi S. C. $\mathrm{H}_{2} \mathrm{~S}$ ameliorates oxidative and proteolytic stresses and protects the heart against adverse remodeling in chronic heart failure. Am. J. Physiol. Heart Circ. Physiol. 2010;298(2):451-456.

82. Warenycia M. W., Goodwin L. R., Benishin C. G., Reiffenstein R. J., Francom D. M., Taylor J. D., 
Dieken F. P. Acute hydrogen sulfide poisoning. Demonstration of selective uptake of sulfide by the brainstem by measurement of brain sulfide levels. Biochem. Pharmacol. 1989;38(6):973981.

83. Voloshchuk N. I., Taran I. V. Acute toxicity of hydrogen sulfide and its influence on the antiinflammatory effect of diclophenac in experiment. Med. Chem. 2011;13(4):88-90. (In Ukrainian).

84. Nishikawa H., Hayashi H., Kubo S., TsubotaMatsunami M., Sekiguchi F., Kawabata A. Inhibition by hydrogen sulfide of rabbit platelet aggregation and calcium mobilization. Biol. Pharm. Bull. 2013;36(8):1278-1282.

85. Gu X., Zhu Y. Z. Therapeutic applications of organosulfur compounds as novel hydrogen sulfide donors and/or mediators. Expert Rev. Clin. Pharmacol. 2011;4(1):123-133.

86. Wallace J. L., Dicay M., McKnight W., Martin G. R. Hydrogen sulfide enhances ulcer healing in rats. FASEB J. 2007;21:4070-4076.

87. Sen U., Vacek T. P., Hughes W. M., Kumar M., Moshal K. S., Tyagi N., Metreveli N., Hayden M. R., Tyagi S. C. Cardioprotective role of sodium thiosulfate on chronic heart failure by modulating endogenous $\mathrm{H}_{2} \mathrm{~S}$ generation. Pharmacology. 2008;82(3):201-213.

88. Zaichko N. V., Platonova T. N., Chernishenko T. M., Grinenko T. V., Yusova E. I. Influence of hydrogen sulfide on hemostasis in rats. Med. Perspect. 2010;15(1):15-20. (In Ukrainian).

89. Francescato H. D., Chierice J. R., Marin E. C., Cunha F. Q., Costa R. S., Silva C. G., Coimbra T. M. Effect of endogenous hydrogen sulfide inhibition on structural and functional renal disturbances induced by gentamicin. Braz. J. Med. Biol. Res. 2012;45(3): 244-249.

90. Fiorucci S., Distrutti E., Cirino G., Wallace J. L. The emerging roles of hydrogen sulfide in the gastrointestinal tract and liver. Gastroenterology. 2006;131(1):259-271.

91. Wallace J.L., Caliendo G., Santagada V., Cirino G. Markedly reduced toxicity of a hydrogen sulphide-releasing derivative of naproxen (ATB346). Br. J. Pharmacol. 2010;159(6):1236-1246.

92. Wiliński B., Wiliński J., Somogyi E., Piotrowska J., Góralska M. Atorvastatin affects the tissue concentration of hydrogen sulfide in mouse kidneys and other organs. Pharmacol. Rep. 2011;63(1):184-188.
93. Bilska A., Iciek M., Kwiecień I., Kaniecki K., Paliborek M., Somogyi E., Piotrowska J., Wiliński B., Góralska M., Srebro Z., Włodek L. Effects of aspirin on the levels of hydrogen sulfide and sulfane sulfur in mouse tissues. Pharmacol. Rep. 2010;62(2):304-310.

94. Wiliński B., Wiliński J., Somogyi E., Piotrowska J., Góralska M. Digoxin increases hydrogen sulfide concentrations in brain, heart and kidney tissues in mice. Pharmacol. Rep. 2011;63(5):1243-1247.

95. Wiliński J., Somogyi E., Góralska M., Wiliński B., Czarnecka D. Ramipril enhances the endogenous hydrogen sulfide tissue concentration in mouse heart and brain. Folia Med. Cracov. 2008;49(34):123-130.

96. Wiliński B., Wiliński J., Somogyi E., Piotrowska J., Opoka W. Metformin raises hydrogen sulfide tissue concentrations in various mouse organs. Pharmacol. Rep. 2013;65(3):737742.

97. Bełtowski J., Jamroz-Wiśniewska A. Modulation of H(2)S metabolism by statins: a new aspect of cardiovascular pharmacology. Antioxid. Redox Signal. 2012;17(1):81-94.

98. Yoltukhivskyy M. M. Effect of DLPropargylglycine and sodium hydrosulfide on cisplatin-induced changes of renal functions in rats. J. VNMU. 2012;16(2):257-262. (In Ukrainian).

99. Wang X., Han A., Wen C., Chen M., Chen X., Yang X., Ma J., Lin G. The Effects of $\mathrm{H}_{2} \mathrm{~S}$ on the activities of CYP2B6, CYP2D6, CYP3A4, CYP2C19 and CYP2C9 in vivo in rat. Int. J. Mol. Sci. 2013;14(12):24055-24063.

100. Zaichko N. V., Olhovskiy A. S., Yurchenko P. A. Microelements complex esmin protects the age-related changes of hydrogen sulfide tissues formation in rats. Materials of the 7th LvivLublin Conference of Experimental and Clinic Biochemistry. Lviv, Ukraine, 2013. P. 191.

101. Yang G., Pei Y., Teng H., Cao Q., Wang R. Specificity protein-1 as a critical regulator of human cystathionine gamma-lyase in smooth muscle cells. J. Biol. Chem. 2011;286(30):2645026460.

102. Strutyns'ka N. A., Semenykhina O. M., Chorna S. V., Vavilova H. L., Sahach V. F. Hydrogen sulfide inhibits $\mathrm{Ca}\left({ }^{2+}\right)$-induced mitochondrial permeability transition pore opening in adult and old rat heart. Fiziol. Zhurn. 2011;57(6):3-14. (In Ukrainian). 
103. Semenykhina O. M., Strutyns'ka N. A., Bud'ko A. Iu., Vavilova H. L., Sahach V. F. Effect of hydrogen sulfide donor $\mathrm{NaHs}$ on the functional state of the respiratory chain of the rat heart mitochondria. Fiziol. Zhurn. 2013;59(2):9-17. (In Ukrainian).

104. Shimanskaia T. V., Strutinskaia N. A., Vavilova G. L., Goshovskaia Iu. V., Semenikhina E. N., Sagach V. F. Cyclosporin A-sensitive mitochondrial pore as a target of cardioprotective action of hydrogen sulfide donor. Ross. Fiziol. Zhurn. im. I. M. Sechenova. 2013;99(2):261-272. (In Russian).

105. Wang Q., Wang X. L., Liu H. R., Rose P., Zhu Y. Z. Protective effects of cysteine analogues on acute myocardial ischemia: novel modulators of endogenous $\mathrm{H}(2) \mathrm{S}$ production. Antioxid. Redox Signal. 2010;12(10):1155-1165.

Received 15.03.2014 